Supporting Information

\title{
Convergent solid-phase synthesis of macromolecular MUC1 models truly mimicking serum glycoprotein biomarkers of interstitial lung diseases
}

\author{
Naoki Ohyabu, ${ }^{\dagger,}$ Kiyoshi Kakiya, ${ }^{\#}$ Yasuhiro Yokoi, ${ }^{\ddagger}$ Hiroshi Hinou, ${ }^{\ddagger},{ }^{\ddagger}$ and Shin-Ichiro \\ Nishimura*t, $\$$ \\ ${ }^{\dagger}$ Shionogi \& Company, Ltd., 3-1-1, Futaba-cho, Toyonaka-shi, Osaka, 561-0825 Japan \\ \#Shionogi \& Company, Ltd., 2-1-3, Kuiseterashima, Amagasaki, 660-0813 Japan \\ ${ }^{\ddagger}$ Graduate School of Life Science and Faculty of Advanced Life Science, Hokkaido \\ University, N21, W11, Kita-ku, Sapporo, 001-0021 Japan \\ ${ }^{\S}$ Medicinal Chemistry Pharmaceuticals, Co. Ltd., N21, W12, Kita-ku, Sapporo, 001- \\ 0022 Japan
}

Correspondence should be addressed to S.-I. N. (E-mail: shin@sci.hokudai.ac.jp ) 


\section{Contents}

\section{Materials and methods.}

Reagents and general methods

Synthesis of key peptide segments A (2), B (3), and C (4).

\section{Optimization of the solid-phase fragment condensation.}

Preparation of the resin-bound peptides/glycopeptides

Condensation of the key segments with resin-bound peptide/glycopeptide

\section{Convergent solid-phase synthesis of 77-mer MUC1 glycopeptides.}

Synthesis of 77-mer asialo-MUC1 glycopeptide (6).

Enzymatic conversion of compound 6 into 77-mer sialyl-MUC1 glycopeptide (1).

Chiral purity of 77-mer MUC1 glycopeptides tested by Marfey's method.

Characterization of synthetic MUC1 glycopeptides by ELISA (EITEST ${ }^{\circledR}$ KL6). 


\section{Materials and methods.}

Reagents and general methods. All commercially available solvents and reagents were used without purification. H-Val-2-ClTrt resin, H-Asp $\left(\mathrm{O}^{t} \mathrm{Bu}\right)-2-\mathrm{ClTrt}$ resin, H-Gly-2ClTrt resin ${ }^{\mathrm{S} 1, \mathrm{~S} 2}$ and Rink amide PEGA resin ${ }^{\mathrm{S} 3, \mathrm{~S} 4}$ were purchased from Nova Biochem (now Merck Bioscience) and $N$-fluorenylmethoxycarbonyl ( $N^{\alpha}$-Fmoc)-amino acid derivatives except for glycosylated compounds were purchased from Nova Biochem (now Merck Bioscience) and Peptide Institute Inc. Convergent solid-phase glycopeptide syntheses were performed on a commercial laboratory microwave reactor (IDX corporation Green Motif I). Alpha 2,3-(O)-sialyltransferase ( $\alpha 2,3-(O)-\operatorname{SiaT})$ was purchased from Calbiochem and CMP-Neu5Ac was purchased from Yamasa Co.. MALDI-TOFMS data were recorded and measured on a Bruker Ultraflex II and Autoflex machine using DHB as matrix. DHB $(10 \mathrm{mg})$ dissolved in $\mathrm{H}_{2} \mathrm{O}(1.0 \mathrm{ml})$. Analytical and preparative RP-HPLC were performed on a Hitachi HPLC system equipped with an L-2130 intelligent pump and L-2420 UV detector or equipped with an L-7100 intelligent pump and an L-7405 UV detector, and Shimadzu HPLC system equipped with an LC-20AD pump, an SPD-M20A diode array detector and an LCMS2010EV liquid chromatograph mass spectrometer using a reversed-phase C18 column, Inertsil ODS-3, $4.6 \times 250 \mathrm{~mm}$ I.D. (GL Science Inc.) at a flow rate of $1.0 \mathrm{ml} / \mathrm{min}$. EITEST $^{\circledR}$ KL-6 was purchased from Sanko Junyaku Co., Ltd. 96 well microplate reader was recorded by a TECAN SUNRISE THERMO. The chromatographies were monitored by absorption at $210 \mathrm{~nm}, 220 \mathrm{~nm}$ or $254 \mathrm{~nm}$. Electrospray ionization mass spectrometry (HR-ESI-MS: JEOL JMS-700TZ) and amino acid analyses (Procise491 cLC, Applied Biosystems) were performed in Centre of Instrumental Analysis at Hokkaido University. 
Synthesis of key peptide segments A (2), B (3), and C (4). Protected peptide segments A (2), B (3), and C (4) (Figure S1) were synthesized under microwave irradiation (0-40 $\mathrm{W}, 2450 \mathrm{~Hz}$ ) at $50^{\circ} \mathrm{C}$ on amino acid per-load 2-ClTrt resin (Val; $0.75 \mathrm{mmol} / \mathrm{g}$, Asp; 0.77 $\mathrm{mmol} / \mathrm{g}$, Gly $0.66 \mathrm{mmol} / \mathrm{g}$ ), respectively. Amino acid coupling reaction was agitated for $1 \mathrm{hr}$ under room temperature with the solution of $N^{\alpha}$-Fmoc-protected amino acids in DMF containing HBTU, ${ }^{\mathrm{S} 5} \mathrm{HOBt}^{\mathrm{S} 6}$ and DIEA. Single coupling steps were performed with conditional capping. The following commercially available protected amino acids were used for the synthesis of these three segments: $N^{\alpha}$-Fmoc-Ala-OH, $N^{\alpha}$-Fmoc$\operatorname{Arg}(\mathrm{Pbf})-\mathrm{OH}, N^{\alpha}$-Fmoc-Gly-OH, $N^{\alpha}$-Fmoc-Pro-OH, Fmoc-His(Trt)-OH, and Fmoc$\mathrm{Asp}(\mathrm{O}-\mathrm{t}-\mathrm{Bu})-\mathrm{OH}$. In the present study, two dipeptide derivatives, Fmoc-Ala-Pro-OH and Fmoc-His(Trt)-Gly-OH, were also prepared via Fmoc-Ala-Pro-OBn and FmocHis(Trt)-Gly-OBn made by a common solution-phase synthesis and used in order to facilitate rapid and large-scale solid-phase synthesis of the three peptide segments. After the coupling reactions, unreacted amino groups on the resin were acetylated with a solution of $\mathrm{Ac}_{2} \mathrm{O}(4.75 \%, \mathrm{v} / \mathrm{v})$, DIEA $(2.25 \%, \mathrm{v} / \mathrm{v})$, and HOBt $(13 \mathrm{mM})$ in DMF for 3 min. $N^{\alpha}$-Fmoc groups were cleaved by $20 \%(\mathrm{v} / \mathrm{v})$ piperidine in DMF for $20 \mathrm{~min}$. After completion of the synthesis, the resin having the protected peptide was treated with AcOH-TFE- $\mathrm{CH}_{2} \mathrm{Cl}_{2}(1: 1: 8, \mathrm{v} / \mathrm{v} / \mathrm{v})$ at room temperature for $1 \mathrm{hr}$ and the solution was separated by filtration. After concentration of the solution under $20^{\circ} \mathrm{C}$, residual peptide was added ether and decanted. Crude products were purified by preparative RP-HPLC according to the following conditions. [Column, Inertsil ODS-3 (10 x $250 \mathrm{~mm})$; flow rate, $4.0 \mathrm{ml} / \mathrm{min}$; elution buffer $\mathrm{A}$ : $\mathrm{H}_{2} \mathrm{O}$ containing $0.1 \%$ TFA, buffer $\mathrm{B}$ : $\mathrm{MeCN}$ containing $0.1 \%$ TFA, in case for compounds having sialic acid residues, buffer A, $\mathrm{H}_{2} \mathrm{O}$ containing $25 \mathrm{mM}$ ammonium acetate, buffer B MeCN containing $10 \%$ buffer A; composition of the solvent, $0-45 \mathrm{~min}$ in a linear gradient flow from $(\mathrm{A} / \mathrm{B})=(98 / 2)$ to $(85 / 15)$ or $(80 / 20)$; Detector UV at $220 \mathrm{~nm}]$. 
<smiles>C[C@H](NC(=O)C1CCCN1C(=O)[C@H](CCCNC(=N)N[Pb])NC(F)F)C(=O)N1CCC[C@H]1C(=O)NCC(=O)O</smiles>

Fmoc-Arg(Pbf)-Pro-Ala-Pro-Gly-OH

segment $A(2)$<smiles>CCCCOC(=O)C[C@H](NC(=O)[C@@H]1CCCN1C(=O)[C@H](C)NC(F)F)C(=O)O</smiles>

Fmoc-Ala-Pro-Asp(tBu)-OH segment $B(3)$<smiles>CCCn1cnc(C[C@H](NC(=O)[C@H](C)NC(=O)[C@@H]2CCCN2C(=O)[C@@H]2CCCN2C(=O)[C@H](C)NC(F)F)C(=O)NCC(=O)N[C@@H](C(=O)O)C(C)C)c1</smiles>

Fmoc-Ala-Pro-Pro-Ala-His(Trt)-Gly-Val-OH segment C (4)

Figure S1. Three protected peptides as key segment A (2), B (3), and C (4). 
Segment A: Fmoc-Arg(Pbf)-Pro-Ala-Pro-Gly-OH (2). Protected peptidyl-resin was synthesized using pre-load H-Gly-2-ClTrt resin (300 mg of resin on loaded $0.66 \mathrm{mmol} / \mathrm{g}$ ), Fmoc-Ala-Pro-OH, $N^{\alpha}$-Fmoc-Arg(Pbf)-OH, and $N^{\alpha}$-Fmoc-Pro-OH. The resin having the protected peptide was treated with $\mathrm{AcOH}-\mathrm{TFE}-\mathrm{CH}_{2} \mathrm{Cl}_{2}(1: 1: 8, \mathrm{v} / \mathrm{v} / \mathrm{v})$ at room temperature for 1 $\mathrm{hr}$ and the resin filtered and washed with $\mathrm{CH}_{2} \mathrm{Cl}_{2}$. After concentration of the solution, subsequent purification of the crude product by preparative RP-HPLC [Column, Inertsil ODS-3 (10 x $250 \mathrm{~mm}$ ); flow rate, $4.0 \mathrm{ml} / \mathrm{min}$; elution buffer $\mathrm{A}: \mathrm{H}_{2} \mathrm{O}$ containing $0.3 \% \mathrm{FA}$, buffer B: MeCN containing $0.3 \%$ FA composition of the solvent, $0-45 \mathrm{~min}$ in a linear gradient flow from $(\mathrm{A} / \mathrm{B})=(60 / 40)$ to $(10 / 90)$; Detector UV at $254 \mathrm{~nm}$ ] gave compound $2(202 \mathrm{mg}, 63 \%$ based on pre-loaded amount). ESI-HRMS: $\mathrm{m} / \mathrm{z}$ calcd for $\mathrm{C}_{49} \mathrm{H}_{62} \mathrm{~N}_{8} \mathrm{O}_{11} \mathrm{SNa}[\mathrm{M}+\mathrm{Na}]^{+}$993.4156, found 993.4156. Amino acid analysis: Ala (1) 1.0, Arg (1) 1.0, Gly (1) 1.0, Pro (2) 2.1. ${ }^{1} \mathrm{H}$ NMR (600

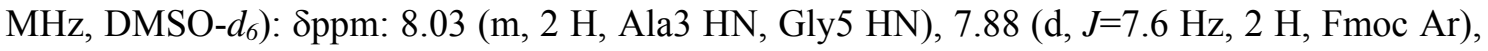
7.70 (m, 2 H, Fmoc Ar), 7.55 (d, J=8.2 Hz, 1 H, Arg1 HN), 7.40 (m, 2 H, Fmoc Ar), 7.31 (m, 2 H, Fmoc Ar), 6.65 (br. s., 1 H, Arg1 NH), 4.47 (t, J=7.0 Hz, 1H, Ala3 Ha), 4.38-4.28 (m, 2 H,

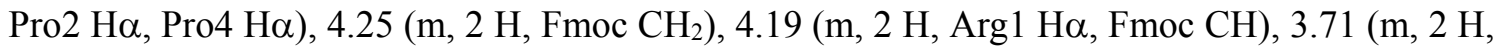

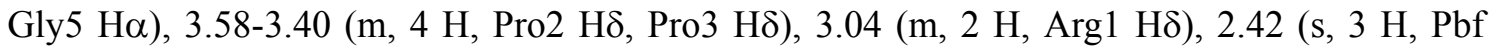

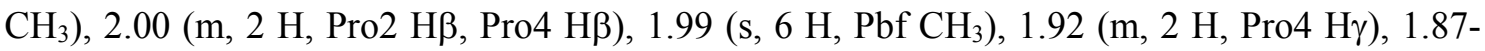

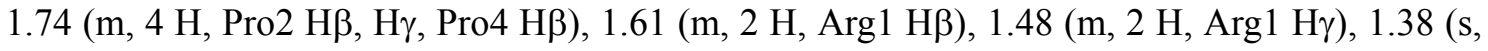
$\left.6 \mathrm{H}, \mathrm{Pbf} \mathrm{CH}_{3}\right), 1.23(\mathrm{~s}, 1 \mathrm{H}, \mathrm{Pbf} \mathrm{CH}), 1.18(\mathrm{~d}, \mathrm{~J}=7.0 \mathrm{~Hz}, 3 \mathrm{H}, \mathrm{Ala} 3 \mathrm{H} \beta) ;{ }^{13} \mathrm{C}$ NMR $(150 \mathrm{MHz}$ (HSQC), DMSO- $d_{6}$ ): $\delta$ ppm: 120.56, 125.54, 127.28, 128.21 (Fmoc Ar), $65.83\left(\mathrm{Fmoc} \mathrm{CH}_{2}\right)$, 59.42 (Pro2 C $\alpha$ ), 59.42 (Pro4 C $\alpha$ ), 52.25 (Arg1 C $\alpha$ ), 47.07 (Fmoc CH), 46.92 (Pro2 C 8$), 46.92$ (Pro4 C 8 ), 46.46 (Ala3 C $\alpha$ ), 40.82 (Gly5 C $\alpha$ ), 39.90 (Arg1 C 8 ), 29.55 (Pro2 C $\gamma$ ), 29.55 (Pro4 $\mathrm{C} \gamma$ ), $29.11\left(\mathrm{Pbf} \mathrm{CH}_{2}\right), 29.00$ (Pro2 $\mathrm{C} \beta$ ), 29.00 (Pro4 $\mathrm{C} \beta$ ), $28.38\left(\mathrm{Pbf} \mathrm{CH}_{3}\right), 28.16(\mathrm{Arg} 1 \mathrm{C} \beta)$, $25.01(\mathrm{Arg} 1 \mathrm{C} \gamma), 20.40\left(\mathrm{Pbf} \mathrm{CH}_{3}\right), 19.15\left(\mathrm{Pbf} \mathrm{CH}_{3}\right), 16.98(\mathrm{Ala3} \mathrm{C} \beta)$. Figure S2 shows analytical HPLC, ESI-HRMS, NMR spectra of the isolated compound 2. 
A

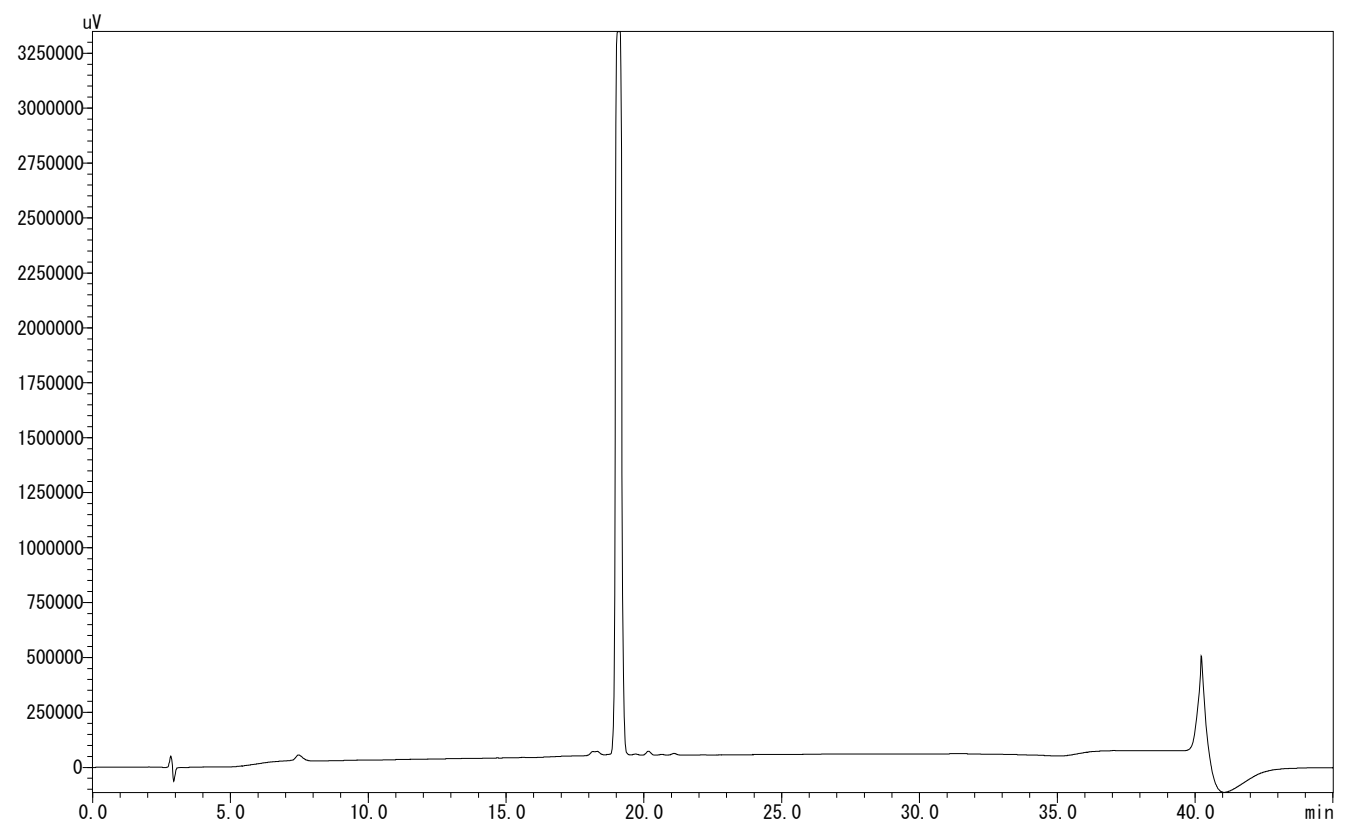

B

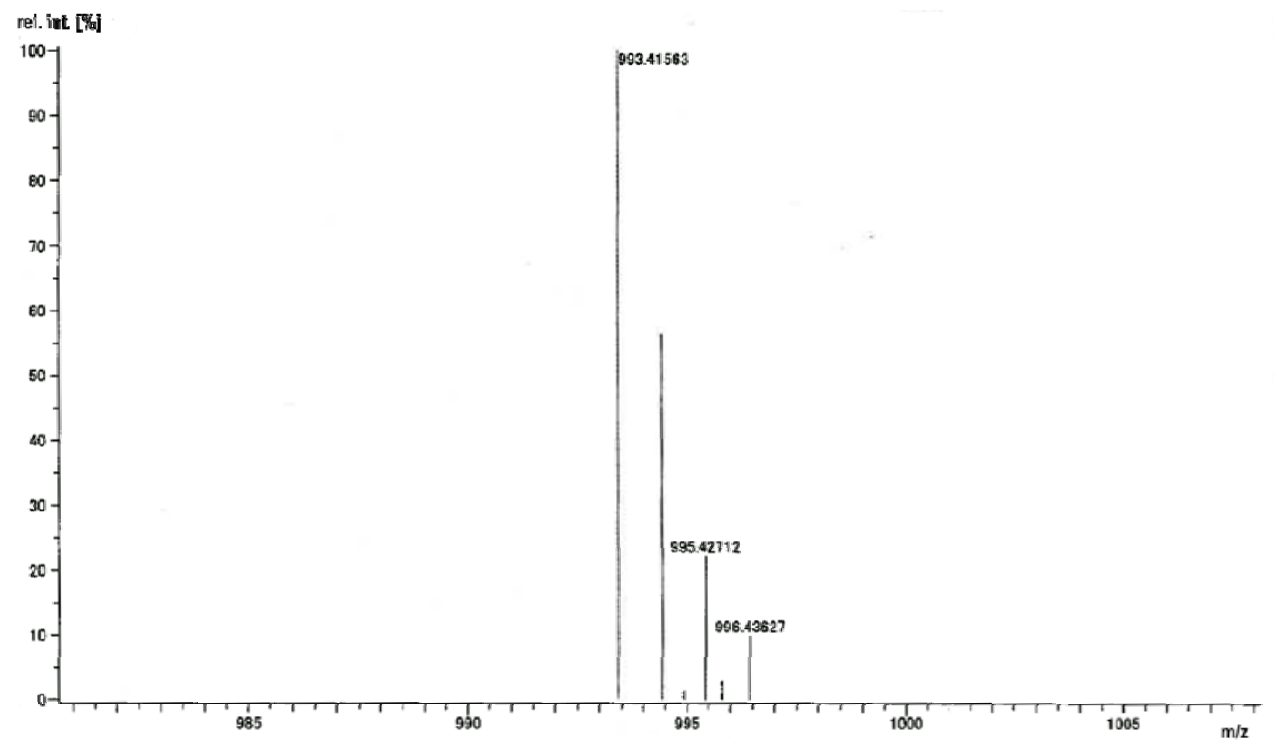


C

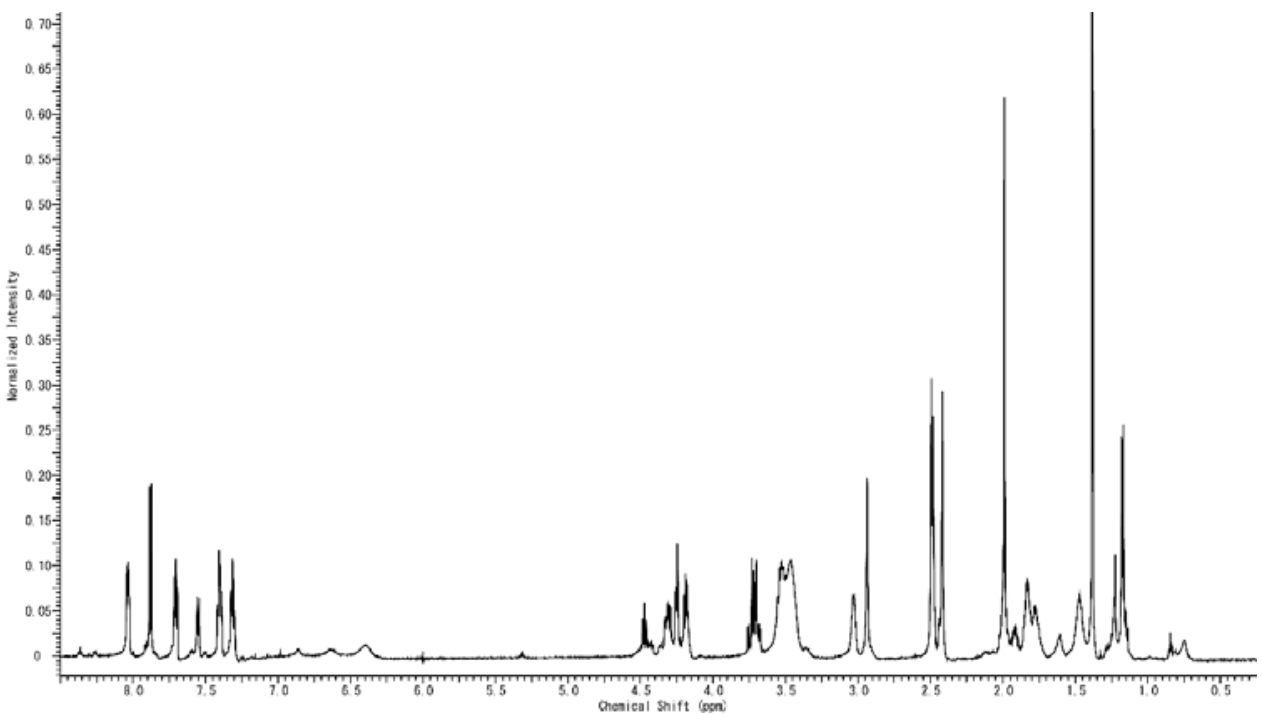

D

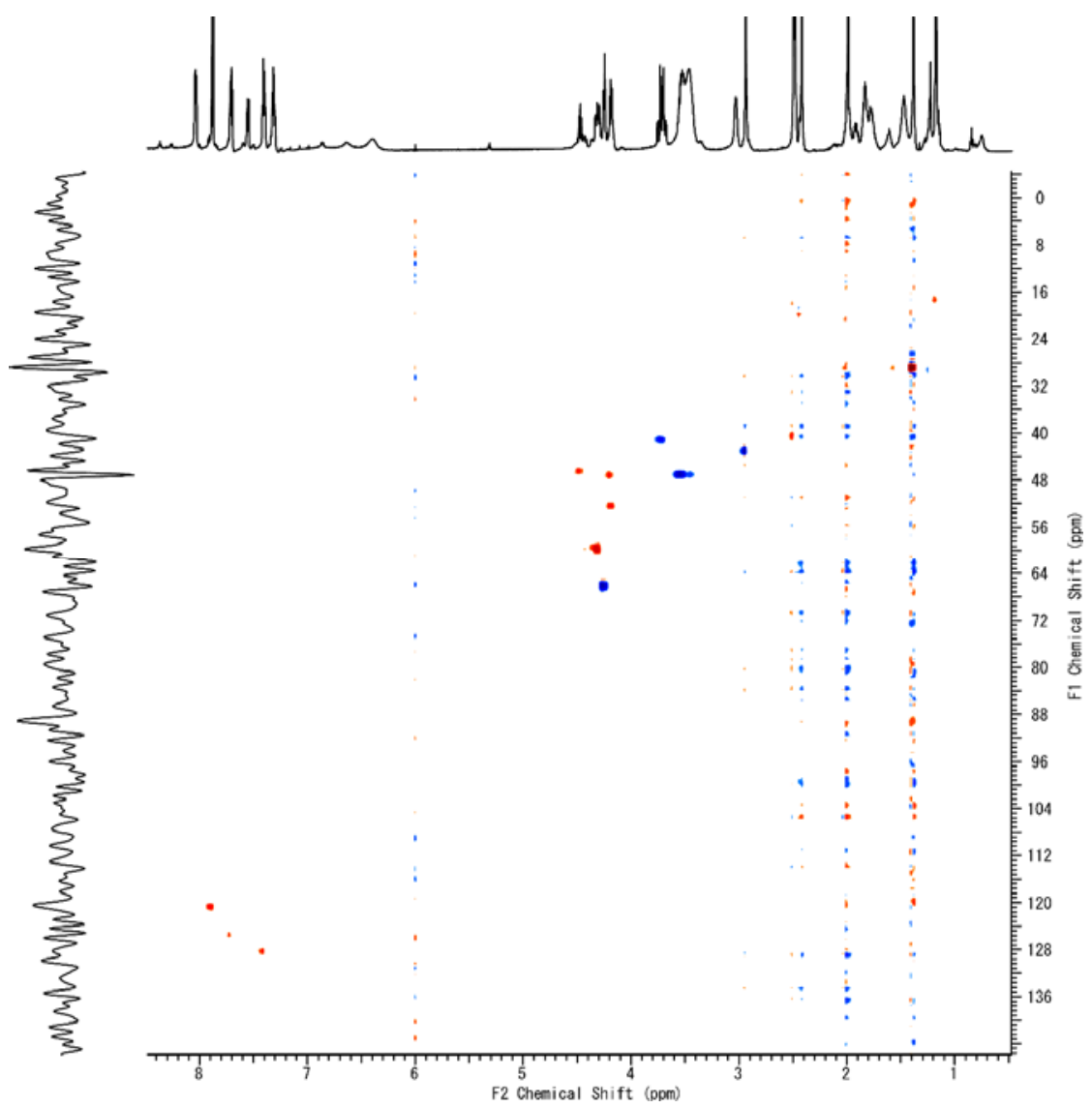

Figure S2. Analytical HPLC (A), ESI-HRMS (B), and NMR spectra (C and D) of the segment A: Fmoc-Arg(Pbf)-Pro-Ala-Pro-Gly-OH (2). Condition of HPLC: Solvent A $0.1 \%$ (formic acid $\left.\mathrm{H}_{2} \mathrm{O}\right)$ and solvent $\mathrm{B}(0.1 \%$ formic acid $\mathrm{MeCN})$, composition of the solvent, 0-30 min in a linear gradient flow from $(\mathrm{A} / \mathrm{B})=(30 / 70)$ to $(10 / 90)$, flow rate $1.0 \mathrm{ml} / \mathrm{min}$, Detector $\mathrm{UV}$ at $210 \mathrm{~nm}$. 
Segment B: Fmoc-Ala-Pro-Asp $\left(\mathbf{O}^{t} \mathbf{B u}\right)-\mathbf{O H}(3)$. Protected peptidyl-resin was synthesized according to using pre-load $\mathrm{H}-\mathrm{Asp}\left(\mathrm{O}^{\mathrm{t}} \mathrm{Bu}\right)-2-\mathrm{ClTrt}$ resin $(300 \mathrm{mg}$ of resin on loaded 0.77 $\mathrm{mmol} / \mathrm{g})$, Fmoc-Ala-Pro-OH, and $N^{\alpha}-\mathrm{Fmoc}-\mathrm{Asp}\left(\mathrm{O}^{t} \mathrm{Bu}\right)-\mathrm{OH}$. The same procedure described in the preparation of compound $\mathbf{2}$ gave compound $\mathbf{3}$ as a lyophilized powder (157 $\mathrm{mg}, 88 \%$ based on pre-loaded amount). ESI-HRMS: $\mathrm{m} / \mathrm{z}$ calcd for $\mathrm{C}_{31} \mathrm{H}_{37} \mathrm{~N}_{3} \mathrm{O}_{8} \mathrm{Na}[\mathrm{M}+\mathrm{Na}]^{+} 602.2478$, found 602.2464. Amino acid analysis: Ala (1) 0.9, Asp (1) 0.9, Pro (1) 1.0. ${ }^{1} \mathrm{H}$ NMR (600 MHz,

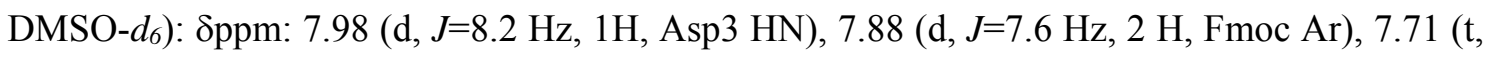
$J=7.9$ Hz, 2 H, Fmoc Ar), 7.58 (d, J=7.6 Hz, 1H, Ala1 HN), 7.41 (t, J=7.3 Hz, 2 H, Fmoc Ar),

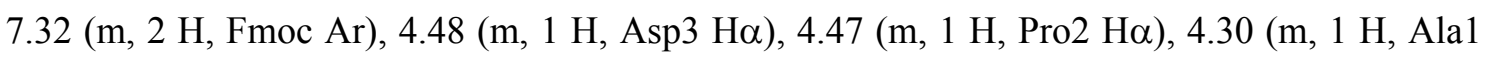
$\mathrm{H \alpha}$ ), 4.25 (m, 2 H, Fmoc $\mathrm{CH}_{2}$ ), 4.19 (m, 1 H, Fmoc CH), 3.57 (m, 1 H, Pro3 Hס), 3.53 (m, 1 H,

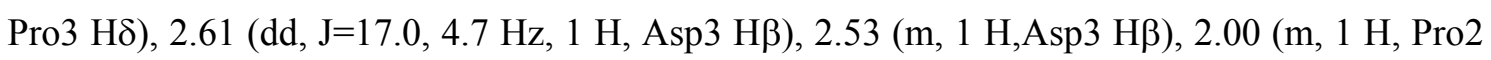
$\mathrm{H} \beta$ ), 1.91-1.81 (m, $3 \mathrm{H}$, Pro2 H $\beta, \mathrm{H} \gamma), 1.38$ (s, $9 \mathrm{H}, \mathrm{tBu} \mathrm{CH}$ ), 1.21 (m, $3 \mathrm{H}$, Ala1 $\mathrm{H} \beta$ ); ${ }^{13} \mathrm{C}$

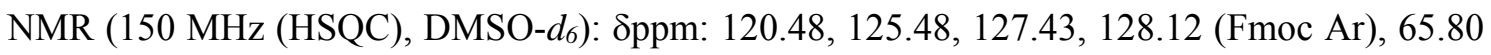

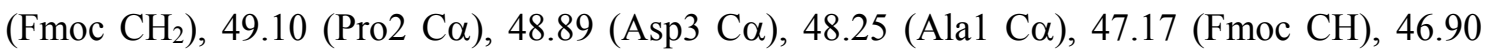
(Pro2 C 8 ), 37.39 (Asp3 C $\beta$ ), 28.98 (Pro2 C $\beta$ ), 27.87 ( $t \mathrm{Bu} \mathrm{CH}_{3}$ ), 25.02 (Pro2 $\mathrm{C} \gamma$ ), 17.03 (Ala1 $\mathrm{C} \beta$ ). Figure S3 shows analytical HPLC, ESI-HRMS, and NMR spectra of the isolated compound 3. 
A

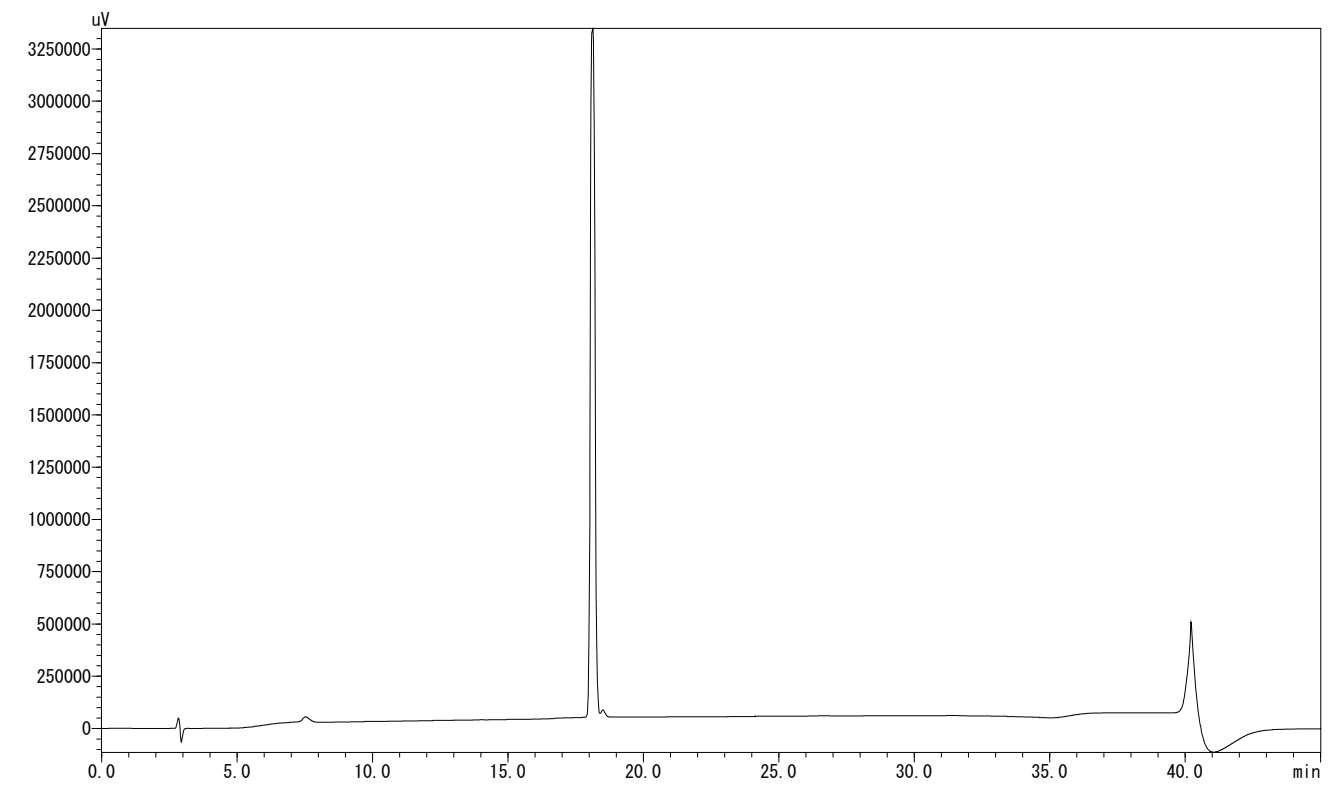

B

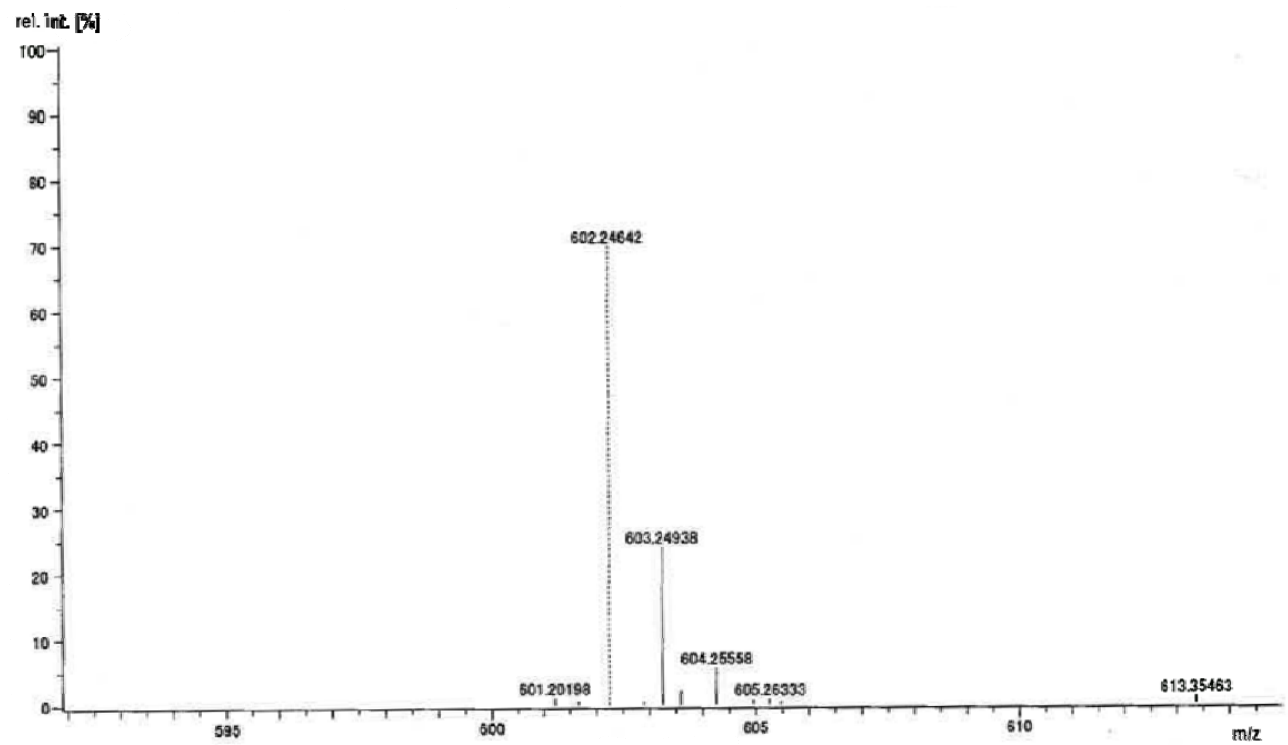


C

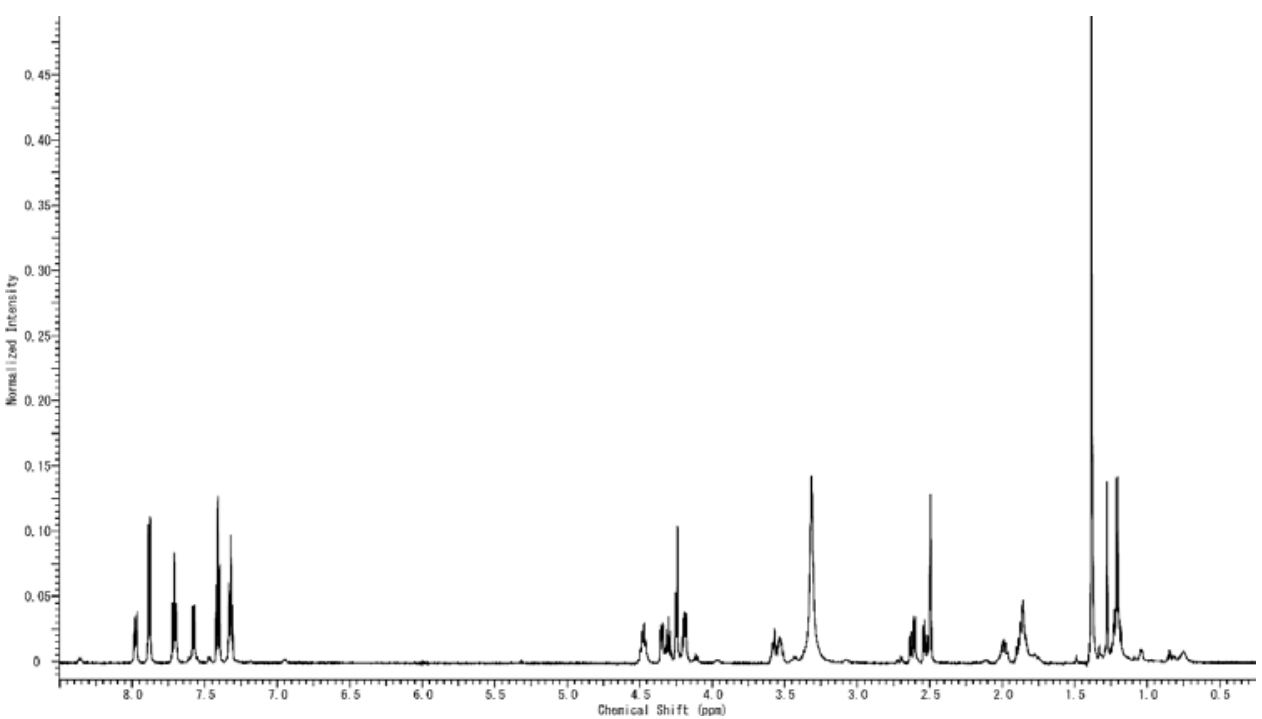

D

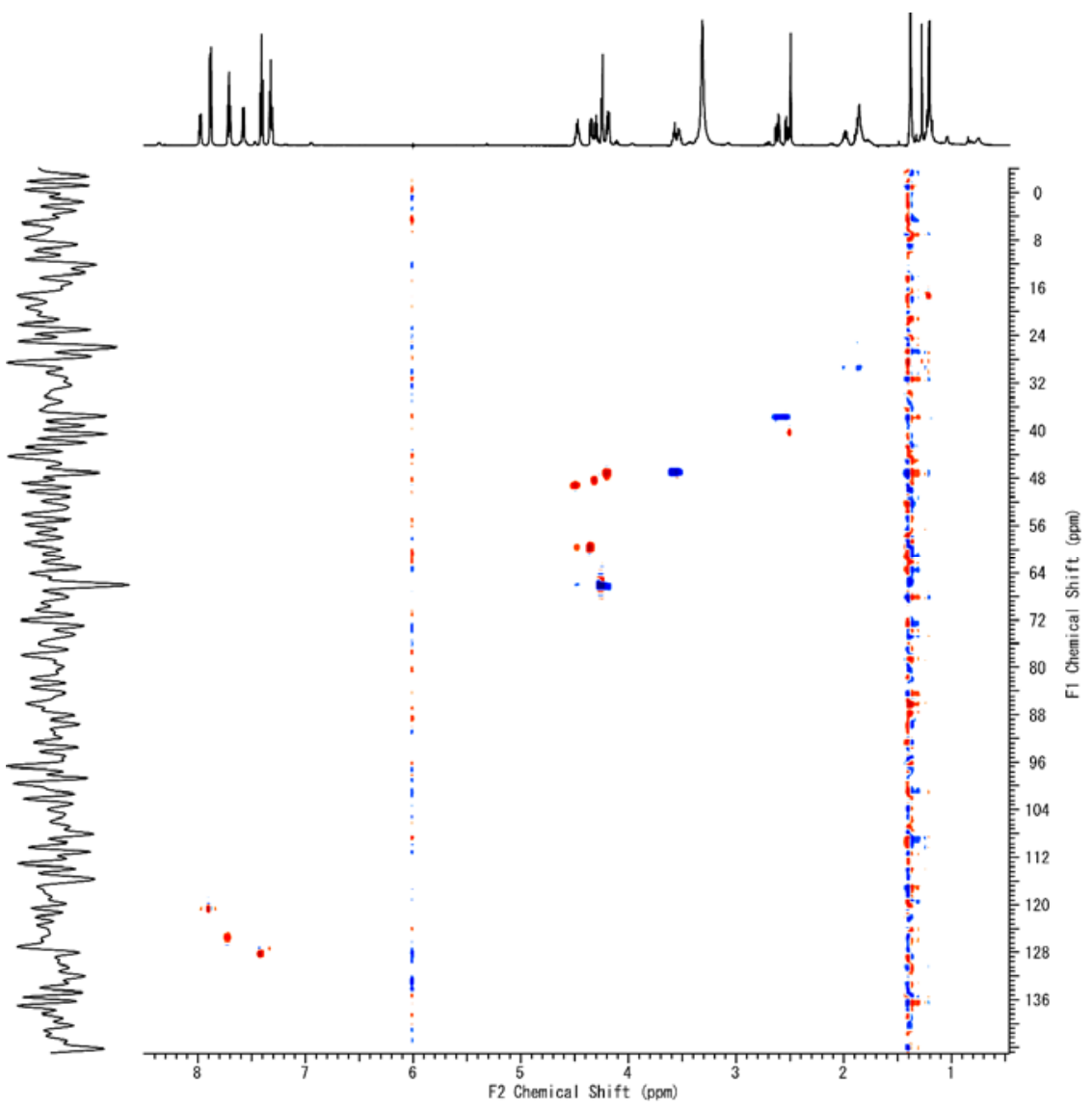

Figure S3. Analytical HPLC (A), ESI-HRMS (B), and NMR spectra (C and D) of the segment B: Fmoc-Ala-Pro-Asp $\left(\mathrm{O}^{t} \mathrm{Bu}\right)-\mathrm{OH}(3)$. HPLC condition; Solvent A $0.1 \%$ (formic acid $\mathrm{H}_{2} \mathrm{O}$ ) and solvent $\mathrm{B}(0.1 \%$ formic acid $\mathrm{MeCN})$, composition of the solvent, $0-30 \mathrm{~min}$ in a linear gradient flow from $(\mathrm{A} / \mathrm{B})=(30 / 70)$ to $(10 / 90)$, flow rate $1.0 \mathrm{ml} / \mathrm{min}$, Detector $\mathrm{UV}$ at $210 \mathrm{~nm}$. 
Segment C: Fmoc-Ala-Pro-Pro-Ala-His(Trt)-Gly-Val-OH (4). Protected peptidyl-resin was synthesized according to the protocol described above by using pre-load H-Val-2-ClTrt resin (300 mg of resin on loaded $0.75 \mathrm{mmol} / \mathrm{g}$ ), Fmoc-His(Trt)-Gly-OH, $N^{\alpha}-\mathrm{Fmoc}-\mathrm{Ala}-\mathrm{OH}$, and $N^{\alpha}$ Fmoc-Pro-OH, respectively. The same procedure described in the preparation of compound 2 gave segment C (4) as a lyophilized powder (210 mg, 84\% based on pre-loaded amount). ESIHRMS: $m / z$ calcd for $\mathrm{C}_{63} \mathrm{H}_{70} \mathrm{~N}_{9} \mathrm{O}_{10}[\mathrm{M}+\mathrm{H}]^{+}$1112.5246, found 1112.5215. Amino acid analysis: Ala (2) 2.0, Gly (1) 1.0, His (1) 1.0, Pro (2) 2.2, Val (1) 1.0. ${ }^{1} \mathrm{H}$ NMR (600 MHz, DMSO-d 6 ): Sppm: 8.01 (m, 2 H, Ala4 HN, Gly6 HN), 7.97 (d, 1 H, J=8.8 Hz, Val7 HN), 7.88 (d, J=7.6 Hz, 2 H, Fmoc Ar), 7.84 (d, J=7.6 Hz, 1 H, His5 HN), 7.71 (t, J=6.4 Hz, 2 H, Fmoc Ar), 7.50 (d, $J=7.6$ Hz, 1 H, Ala1 HN), 7.42-7.22 (m, 16 H, His5 Ar, Val7 HN, Fmoc Ar, Trt Ar), 7.06 (m, 6

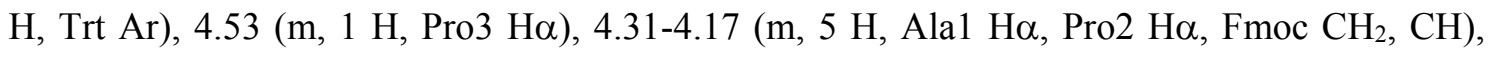

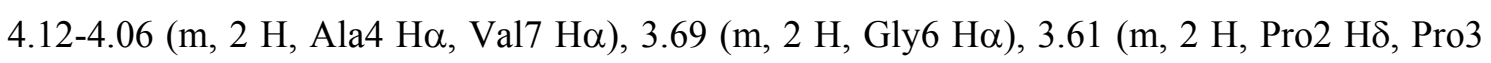

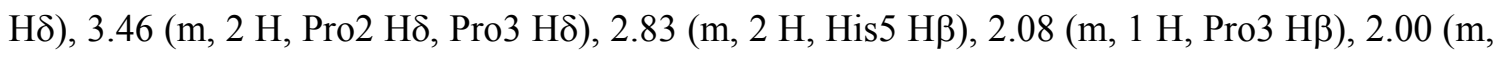

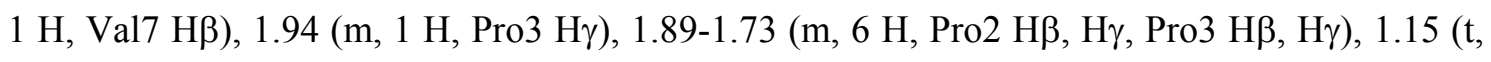
$J=7.6 \mathrm{~Hz}, 6 \mathrm{H}$, Ala1 H $\beta$, Ala4 H $), 0.83$ (dd, $J=8.2,7.0 \mathrm{~Hz}, 6 \mathrm{H}, \mathrm{Val} 7 \mathrm{H} \gamma) ;{ }^{13} \mathrm{C}$ NMR $(150 \mathrm{MHz}$ (HSQC), DMSO-d ${ }_{6}$ ): $\delta p p m: 125.24,128.28,129.54$ (Trt Ar), 120.63, 125.36, 126.76, 127.17 (Fmoc Ar), 119.22 (His5 Ar), $65.97\left(\right.$ Fmoc $\left.\mathrm{CH}_{2}\right), 59.30$ (Pro2 C $\alpha$ ), 57.94 (Pro3 C $\alpha$ ), 57.78 (Val7 C $\alpha$ ), 53.23 (His5 C $\alpha$ ), 48.83 (Ala4 C $\alpha$ ), 48.08 (Ala1 C $\alpha$ ), 47.17 (Fmoc CH), 47.01 (Pro2

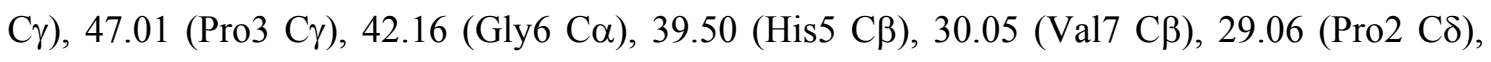
29.06 (Pro3 C 8 ), 28.30 (Pro2 C $\beta$ ), 28.30 (Pro3 C $\beta$ ), 19.75 (Val7 C $\gamma$ ), 18.00 (Ala4 C $\beta$ ), 16.70 (Ala1 C $\beta$ ). Figure S4 shows analytical HPLC, ESI-HRMS, and NMR spectra of the isolated compound 4. 
A

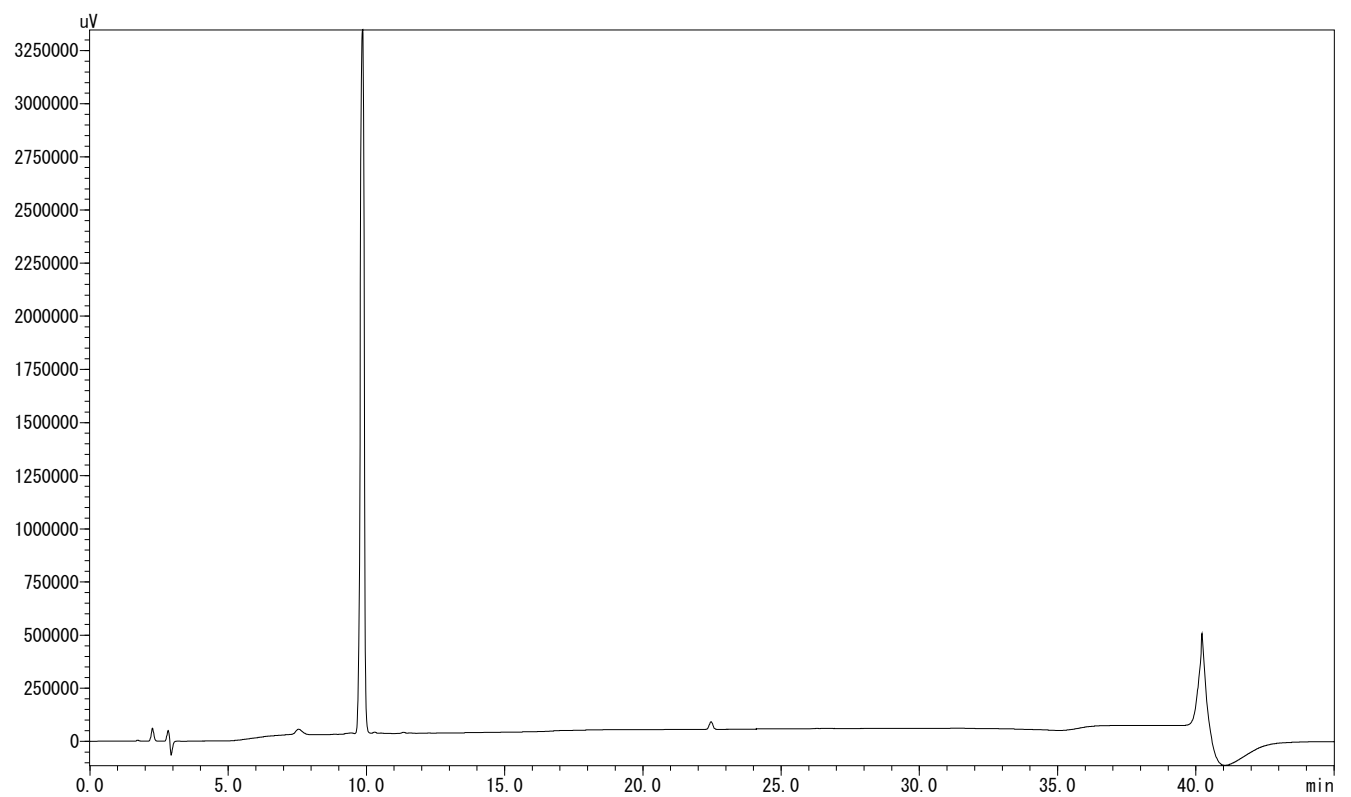

B

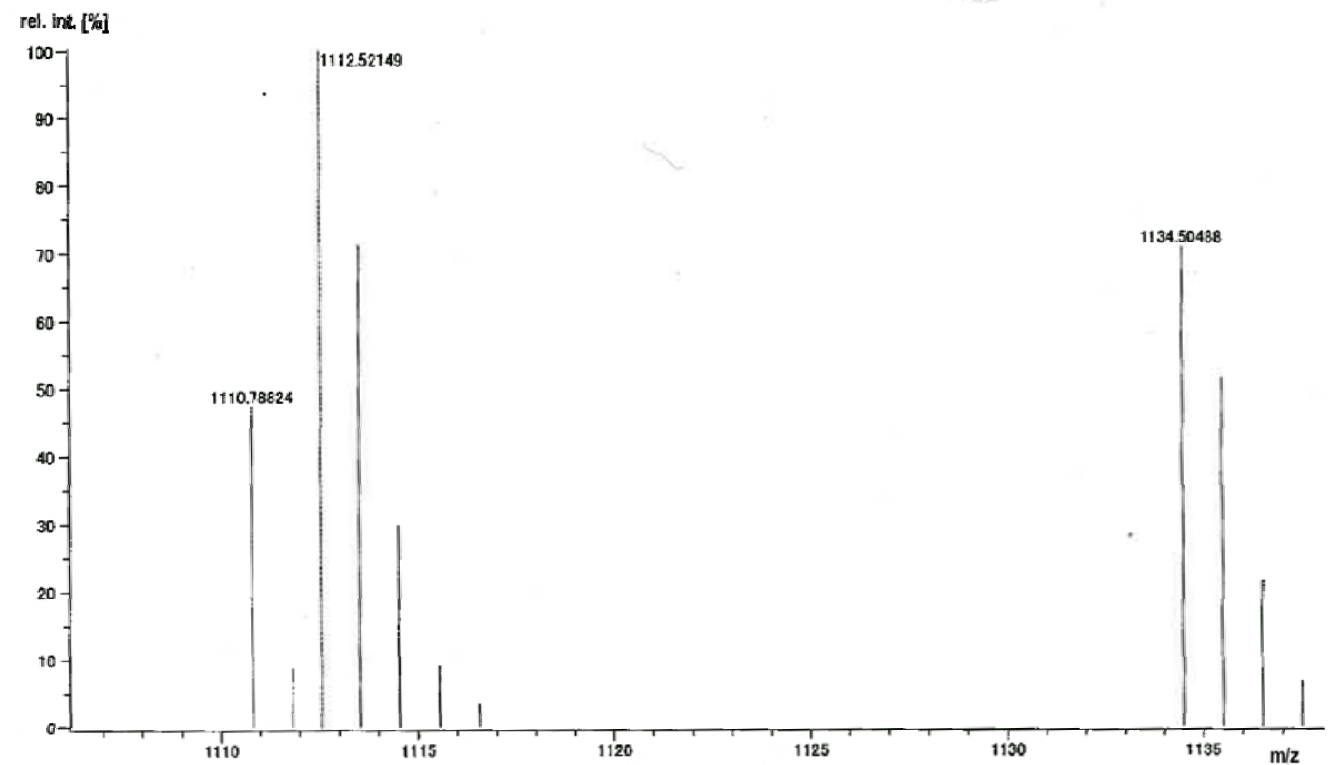


C

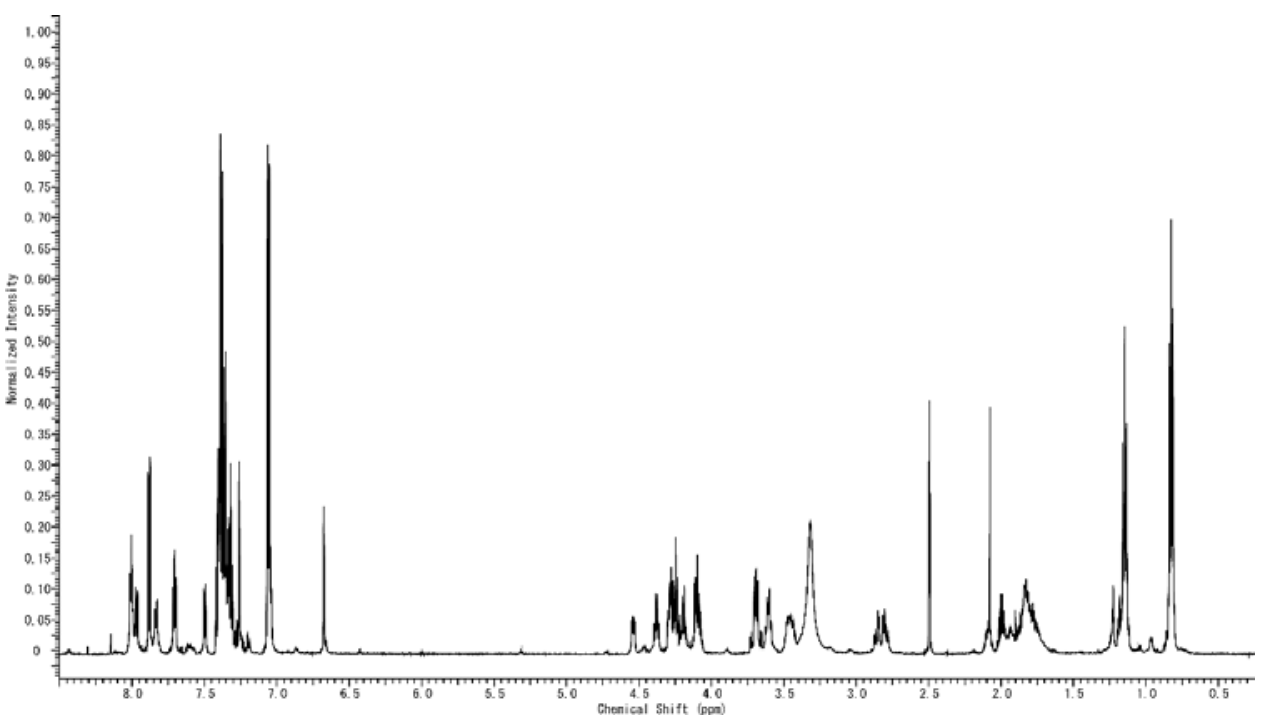

D

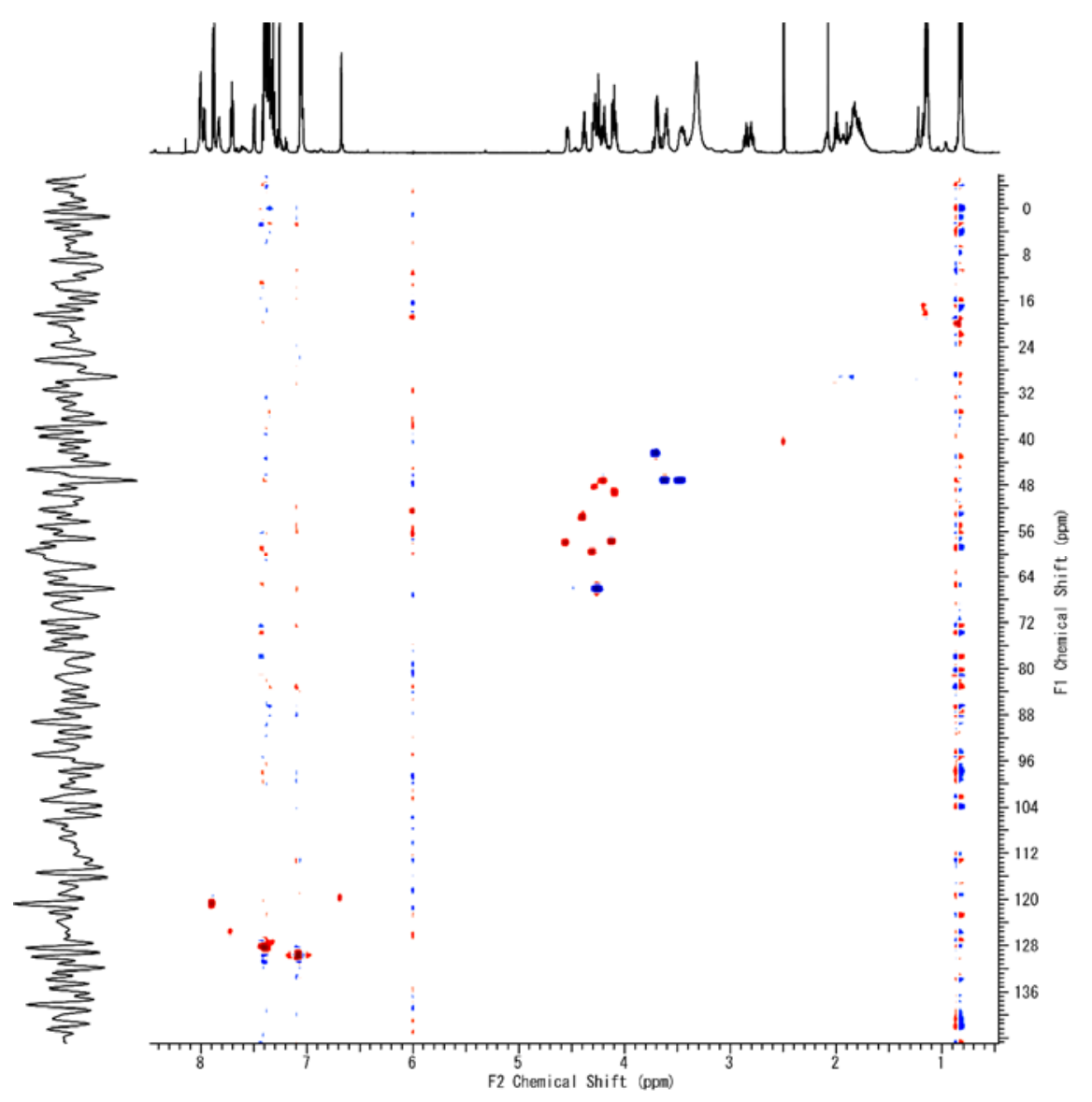

Figure S4. Analytical HPLC (A), ESI-HRMS (B), and NMR spectra (C and D) of the segment C: Fmoc-Ala-Pro-Pro-Ala-His(Trt)-Gly-Val-OH (4). HPLC condition; Solvent A $0.1 \%$ (formic acid $\left.\mathrm{H}_{2} \mathrm{O}\right)$ and solvent $\mathrm{B}(0.1 \%$ formic acid $\mathrm{MeCN})$, composition of the solvent, $0-30$ min in a linear gradient flow from $(A / B)=(30 / 70)$ to $(10 / 90)$, flow rate $1.0 \mathrm{ml} / \mathrm{min}$, Detector UV at 210 $\mathrm{nm}$. 


\section{Optimization of the solid-phase fragment condensation.}

Preparation of the resin-bound peptides/glycopeptides. Peptides and glycopeptides were synthesized on the Rink amide PEGA resin $(0.05 \mathrm{mmol} / \mathrm{g}$ wet volume $)$ using a microwave-assisted coupling reaction. Amino acid coupling reaction was agitated for 5 min under microwave irradiation $(0-40 \mathrm{~W}, 2450 \mathrm{~Hz})$ at $50^{\circ} \mathrm{C}$ with the solution of $N^{\alpha}$ Fmoc-protected amino acids in DMF containing HBTU, HOBt and DIEA. Single coupling steps were performed with conditional capping. The following protected amino acids were used [ $N^{\alpha}$-Fmoc-Ala-OH, $N^{\alpha}$-Fmoc-Arg(Pbf)-OH, $N^{\alpha}$-Fmoc-Asp(O-t$\mathrm{Bu})-\mathrm{OH}, N^{\alpha}$-Fmoc-Gly-OH, $N^{\alpha}$-Fmoc-His(Trt)-OH, $N^{\alpha}$-Fmoc-Pro-OH, $N^{\alpha}$-Fmoc-Ser( $t$ $\left.\mathrm{Bu})-\mathrm{OH}, N^{\alpha}-\mathrm{Fmoc}-\mathrm{Thr}(\mathrm{t}-\mathrm{Bu})-\mathrm{OH}, N^{\alpha}-\mathrm{Fmoc}-\mathrm{Val}-\mathrm{OH}\right]$. The reaction of the sugar amino acids was agitated for 20 min under same manner. The following protected sugar amino acids were used according to the previous reports: ${ }^{\mathrm{S7}-\mathrm{S} 10} N^{\alpha}$-Fmoc$\operatorname{Thr}\left((\mathrm{AcO})_{3}\right.$ GalNAc $\left.\alpha\right)-\mathrm{OH}, N^{\alpha}-\mathrm{Fmoc}-\mathrm{Thr}\left((\mathrm{AcO})_{4} \mathrm{Gal} \beta 1 \rightarrow 3(\mathrm{AcO})_{2}\right.$ GalNAc $\left.\alpha\right)-\mathrm{OH}, N^{\alpha}-$ Fmoc-Thr $\left((\mathrm{AcO})_{4} \mathrm{Gal} \beta 1 \rightarrow 3\left[(\mathrm{AcO})_{3} \mathrm{GlcNAc} \beta 1 \rightarrow 6\right] \mathrm{GalNAc} \alpha\right)-\mathrm{OH}$. After the coupling reaction, unreacted amino groups on the resin were acetylated with a solution of $\mathrm{Ac}_{2} \mathrm{O}$ (4.75\%, v/v), DIEA $(2.25 \%, \mathrm{v} / \mathrm{v})$, and HOBt $(13 \mathrm{mM})$ in DMF for $5 \mathrm{~min} . N^{\alpha}$-Fmoc groups were cleaved by $20 \%(\mathrm{v} / \mathrm{v})$ piperidine in DMF for $3 \mathrm{~min}$ under microwave irradiation. After completion of the coupling reaction, the resin was washed in the same manner as describe above. The resin-bound peptides/glycopeptides were used to next condensation reactions with segment B (3) or C (4).

Condensation of the segments with resin-bound peptide/glycopeptide. Peptide segment B (3) or C (4) was applied in 3 molar excess against the resin-bound peptide/glycopeptide in each reactions. Condensation reactions was carried out using $100 \mathrm{mg}$ of resin-bound peptide/glycopeptide $(5 \mu \mathrm{mol})$. After removal of the $N$-terminal Fmoc group with $20 \%$ piperidine in DMF, the resin was swollen for 1 minute in the reaction solution. The coupling reaction was accomplished in a mixture containing segment B (3) or C (4), DIC (or HBTU), HOOBt $\mathrm{H}^{\mathrm{S} 11, \mathrm{~S} 12}$ (HOBt, $\mathrm{HOAt}^{\mathrm{S} 13, \mathrm{~S} 14}$ or Cl- 
$\left.\mathrm{HOBt}^{\mathrm{S15}}\right)(3: 6: 6$ equiv.) for $10 \mathrm{~min}$ under the microwave irradiation. After condensation and subsequent washing with DMF, unreacted amino groups were end-capped with $\mathrm{Ac}_{2} \mathrm{O}-\mathrm{DIEA}-\mathrm{HOBt} / \mathrm{DMF}$ for $3 \mathrm{~min}$. The resulted resin was subjected to the treatment with with $20 \%$ piperidine in DMF, washed with DMF followed by $\mathrm{CH}_{2} \mathrm{Cl}_{2}$, and dried. Finally, the crude products were released from the resin by treatment with the cleavage cocktail [TFA/TIS/ $\left.\mathrm{H}_{2} \mathrm{O}(95: 2.5: 2.5)\right]$ for $1 \mathrm{hr}$. The mixture was filtered into a tube, the resin was washed with TFA, and all the extracts were collected and evaporated. The product was precipitated from diethyl ether and dried. The products were employed for the quantitative assessment of the stereoselectivity by using RP-HPLC method (Figures S5 S15). The results were summarized in Table S1. 
Table S1. Optimization of the fragment condensation between segment B: Fmoc-AlaPro-Pro-Ala-His(Trt)-Gly-Val-OH (3) and H-Thr(tBu)-Ser(tBu)-Ala-linkamide PEGA resin.

\begin{tabular}{lcccc} 
Entry & Reagents & Solvent & Yield (\%) & Epimer. (\%) \\
1 & $\mathrm{HBTU} / \mathrm{HOBt} / \mathrm{DIEA}$ & $\mathrm{DMF}$ & $>99$ & 28.4 \\
2 & $\mathrm{DIC} / \mathrm{HOOBt}$ & $\mathrm{DMF}$ & $>99$ & 1.1 \\
3 & $\mathrm{DIC} / \mathrm{HOBt}$ & $\mathrm{DMF}$ & $>99$ & 6.4 \\
4 & $\mathrm{DIC} / \mathrm{HOOBt}$ & $\mathrm{NMP}$ & 90.0 & 0.8 \\
5 & $\mathrm{DIC} / \mathrm{HOOBt}$ & $\mathrm{NMP}$ & 73.0 & 5.3 \\
6 & $\mathrm{DIC} / \mathrm{HOOBt}$ & $\mathrm{CH}_{2} \mathrm{Cl}_{2}$ & $>99$ & $<0.3$ \\
7 & $\mathrm{DIC} / \mathrm{HOBt}$ & $\mathrm{CH}_{2} \mathrm{Cl}_{2}$ & $>99$ & 0.7 \\
8 & $\mathrm{DIC} / \mathrm{HOAt}$ & $\mathrm{CH}_{2} \mathrm{Cl}_{2}$ & $>99$ & 0.8 \\
9 & $\mathrm{DIC} / \mathrm{Cl}-\mathrm{HOBt}$ & $\mathrm{CH}_{2} \mathrm{Cl}_{2}$ & $>99$ & $<0.3$ \\
10 & $\mathrm{DIC} / \mathrm{HOOBt}$ & $\mathrm{DMSO}^{2}$ & 72.6 & 3.7 \\
11 & $\mathrm{DIC} / \mathrm{HOBt}$ & $\mathrm{DMSO}^{2}$ & 72.8 & 21.5 \\
12 & $\mathrm{DIC} / \mathrm{HOOBt}$ & $\mathrm{CHCl}_{3} / \mathrm{PhOH}$ & $>99$ & 0.6 \\
13 & $\mathrm{DIC} / \mathrm{HOOBt}$ & $\mathrm{CHCl} / \mathrm{PTFE}$ & 2.8 & 2.4 \\
\hline
\end{tabular}




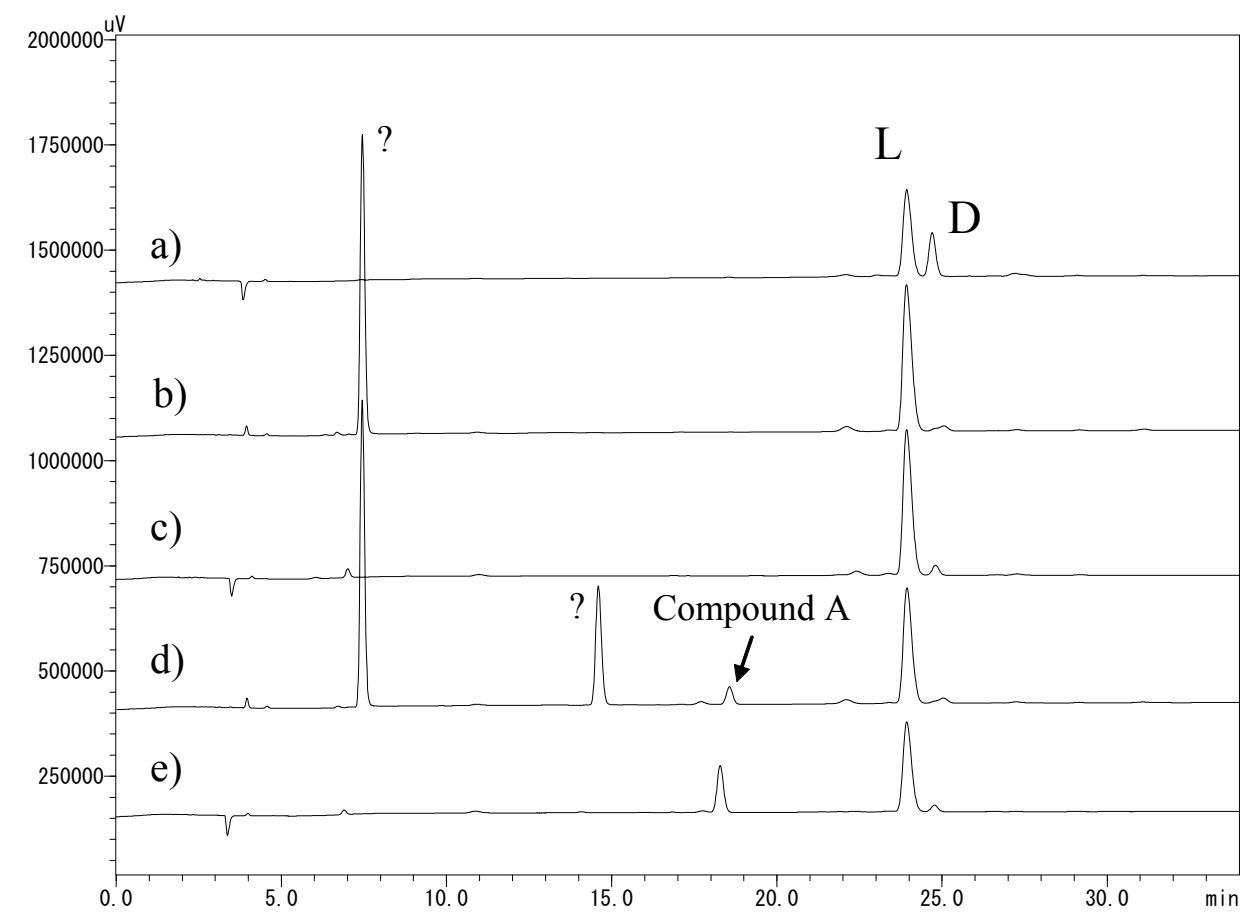

Figure S5. RP-HPLC analysis of the reaction mixture showing Ala-Pro-Asp-Thr-ArgPro-Ala with $L$-Asp and D-Asp synthesized from peptide segment B (Fmoc-Ala-Pro$\left.\mathrm{Asp}\left(\mathrm{O}^{t} \mathrm{Bu}\right)-\mathrm{OH}\right)$ and peptide-bound resin [ $\mathrm{H}_{2} \mathrm{~N}-\mathrm{Th}\left({ }^{\mathrm{t}} \mathrm{Bu}\right)-\mathrm{Arg}(\mathrm{Pbf})-$ Pro-Ala-resin] under various conditions. a) HTBU, HOBt, DIEA/DMF, b) DIC, HOOBt/DMF, c) DIC, HOBt/DMF, d) DIC, HOOBt/NMP, e) DIC, HOBt/NMP (compound A represents Ac-Thr-Arg-Pro-Ala-NH2). HPLC condition: solvent A $(0.1 \%$ TFA in $\left.\mathrm{H}_{2} \mathrm{O}\right)$ and solvent $\mathrm{B}(0.1 \%$ TFA in $\mathrm{MeCN})$, composition of the solvent: $0-30 \mathrm{~min}$ in a linear gradient flow from $(A / B)=(98 / 2)$ to $(90 / 30)$, flow rate $1.0 \mathrm{ml} / \mathrm{min}$, Detector UV at $210 \mathrm{~nm}$. 


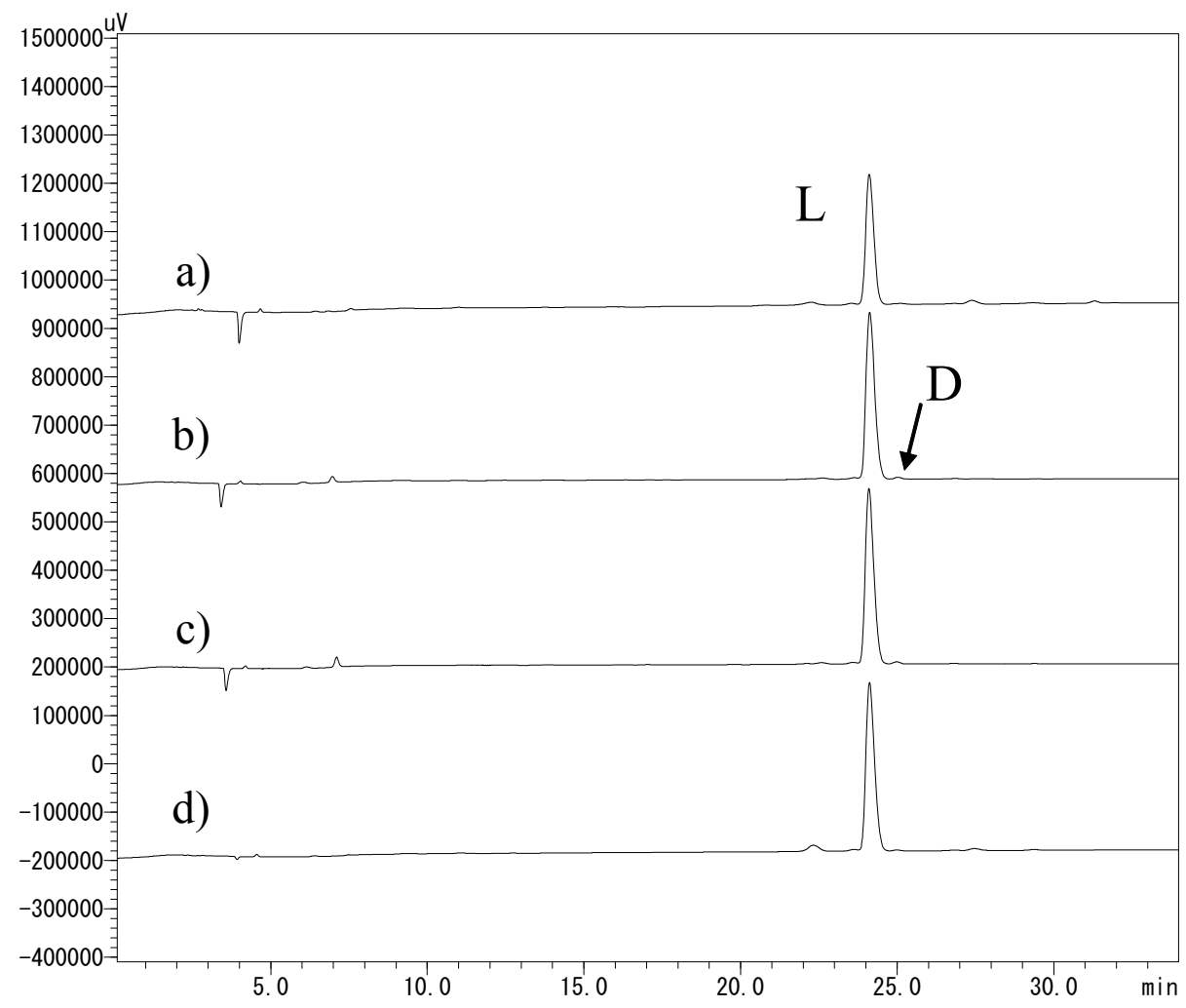

Figure S6. RP-HPLC analysis of the reaction mixture showing Ala-Pro-Asp-Thr-ArgPro-Ala synthesized from the segment B (Fmoc-Ala-Pro-Asp $\left.\left(\mathrm{O}^{\mathrm{t}} \mathrm{Bu}\right)-\mathrm{OH}\right)$ and peptidebound resin $\left[\mathrm{H}_{2} \mathrm{~N}-\mathrm{Thr}\left({ }^{\mathrm{t}} \mathrm{Bu}\right)-\mathrm{Arg}(\mathrm{Pbf})\right.$-Pro-Ala-resin] under the various conditions. a) DIC, $\mathrm{HOOBt} / \mathrm{CH}_{2} \mathrm{Cl}_{2}$, b) DIC, $\mathrm{HOBt} / \mathrm{CH}_{2} \mathrm{Cl}_{2}$, c) DIC, $\mathrm{HOAt} / \mathrm{CH}_{2} \mathrm{Cl}_{2}$, d) DIC, Cl$\mathrm{HOBt} / \mathrm{CH}_{2} \mathrm{Cl}_{2}$. HPLC condition: solvent $\mathrm{A}\left(0.1 \%\right.$ TFA in $\left.\mathrm{H}_{2} \mathrm{O}\right)$ and solvent $\mathrm{B}(0.1 \%$ TFA in $\mathrm{MeCN}$ ), composition of the solvent: 0-30 min in a linear gradient flow from $(A / B)=(98 / 2)$ to $(90 / 30)$, flow rate $1.0 \mathrm{ml} / \mathrm{min}$, Detector $\mathrm{UV}$ at $210 \mathrm{~nm}$. 


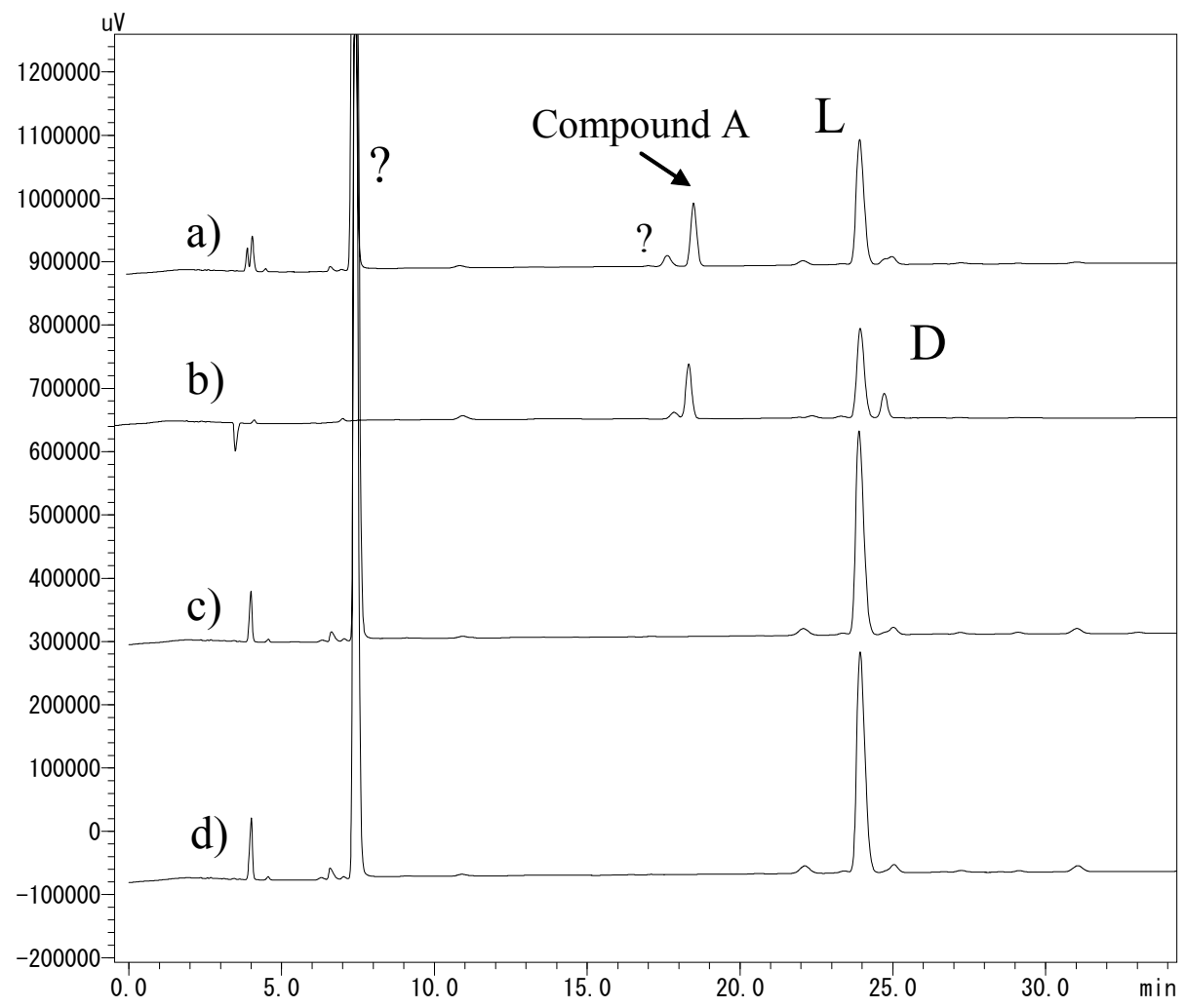

Figure S7. RP-HPLC analysis of the reaction mixture showing Ala-Pro-Asp-Thr-ArgPro-Ala synthesized from the segment B (Fmoc-Ala-Pro-Asp $\left.\left(\mathrm{O}^{t} \mathrm{Bu}\right)-\mathrm{OH}\right)$ and peptidebound resin $\left[\mathrm{H}_{2} \mathrm{~N}-\mathrm{Thr}\left({ }^{\mathrm{t}} \mathrm{Bu}\right)-\mathrm{Arg}(\mathrm{Pbf})-\mathrm{Pro}-\mathrm{Ala}-\mathrm{resin}\right]$ under the various conditions. a) DIC, HOOBt/DMSO, b) DIC, HOBt/DMSO, c) DIC, HOOBt/CHCl $3-\mathrm{PhOH}$, d) DIC, $\mathrm{HOOBt} / \mathrm{CHCl}_{3}$-TFE (compound A represents Ac-Thr-Arg-Pro-Ala-NH2). HPLC condition: solvent $\mathrm{A}\left(0.1 \%\right.$ TFA in $\left.\mathrm{H}_{2} \mathrm{O}\right)$ and solvent $\mathrm{B}(0.1 \%$ TFA in $\mathrm{MeCN})$, composition of the solvent: $0-30 \mathrm{~min}$ in a linear gradient flow from $(\mathrm{A} / \mathrm{B})=(98 / 2)$ to (90/30), flow rate $1.0 \mathrm{ml} / \mathrm{min}$, Detector UV at $210 \mathrm{~nm}$. 

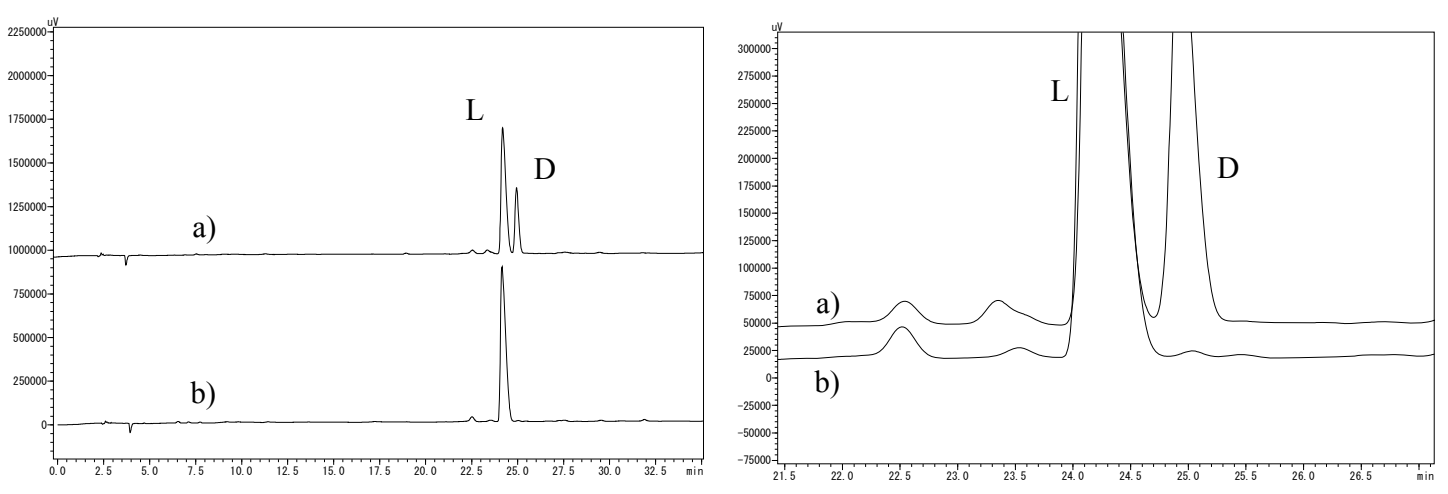

Figure S8. RP-HPLC analysis of the product, Ala-Pro-Asp-Thr-Arg-Pro-Ala synthesized by the coupling between the peptide segment B (Fmoc-Ala-Pro-Asp $\left(\mathrm{O}^{t} \mathrm{Bu}\right)$ $\mathrm{OH})$ and peptide-bound resin $\left[\mathrm{H}_{2} \mathrm{~N}-\mathrm{Thr}\left({ }^{\mathrm{t}} \mathrm{Bu}\right)-\mathrm{Arg}(\mathrm{Pbf})-\right.$ Pro-Ala-resin $]$. a) reaction condition: HTBU, HOBt, DIEA/DMF, b) reaction condition: DIC, $\mathrm{HOOBt} / \mathrm{CH}_{2} \mathrm{Cl}_{2}$. HPLC condition; solvent A $\left(0.1 \%\right.$ TFA in $\left.\mathrm{H}_{2} \mathrm{O}\right)$ and solvent $\mathrm{B}(0.1 \%$ TFA in $\mathrm{MeCN})$, composition of the solvent: $0-30 \mathrm{~min}$ in a linear gradient flow from $(A / B)=(98 / 2)$ to (90/30), flow rate $1.0 \mathrm{ml} / \mathrm{min}$, detector $\mathrm{UV}$ at $210 \mathrm{~nm}$. 


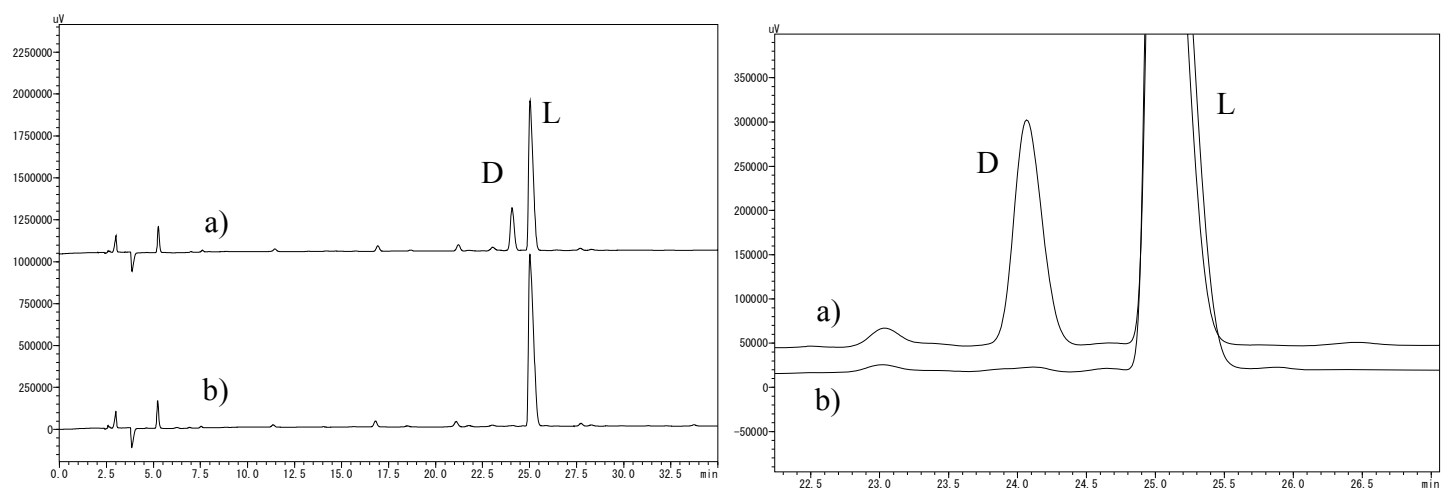

Figure S9. RP-HPLC analysis of the product, Ala-Pro-Asp-Thr(Tn)-Arg-Pro-Ala synthesized by the coupling between the peptide segment B (Fmoc-Ala-Pro-Asp $\left(\mathrm{O}^{t} \mathrm{Bu}\right)$ $\mathrm{OH})$ and glycopeptide-bound $\operatorname{resin}\left[\mathrm{H}_{2} \mathrm{~N}-\mathrm{Thr}\left((\mathrm{AcO})_{3} \mathrm{Tn}\right)-\mathrm{Arg}(\mathrm{Pbf})-\mathrm{Pro}-\mathrm{Ala}-\mathrm{resin}\right]$. a) reaction condition: HTBU, HOBt, DIEA/DMF, b) reaction condition: DIC, $\mathrm{HOOBt} / \mathrm{CH}_{2} \mathrm{Cl}_{2}$. HPLC condition; solvent A $\left(0.1 \%\right.$ TFA in $\left.\mathrm{H}_{2} \mathrm{O}\right)$ and solvent $\mathrm{B}(0.1 \%$ TFA in $\mathrm{MeCN}$ ), composition of the solvent: 0-30 min in a linear gradient flow from $(\mathrm{A} / \mathrm{B})=(98 / 2)$ to $(90 / 10)$, flow rate $1.0 \mathrm{ml} / \mathrm{min}$, detector $\mathrm{UV}$ at $210 \mathrm{~nm}$. 


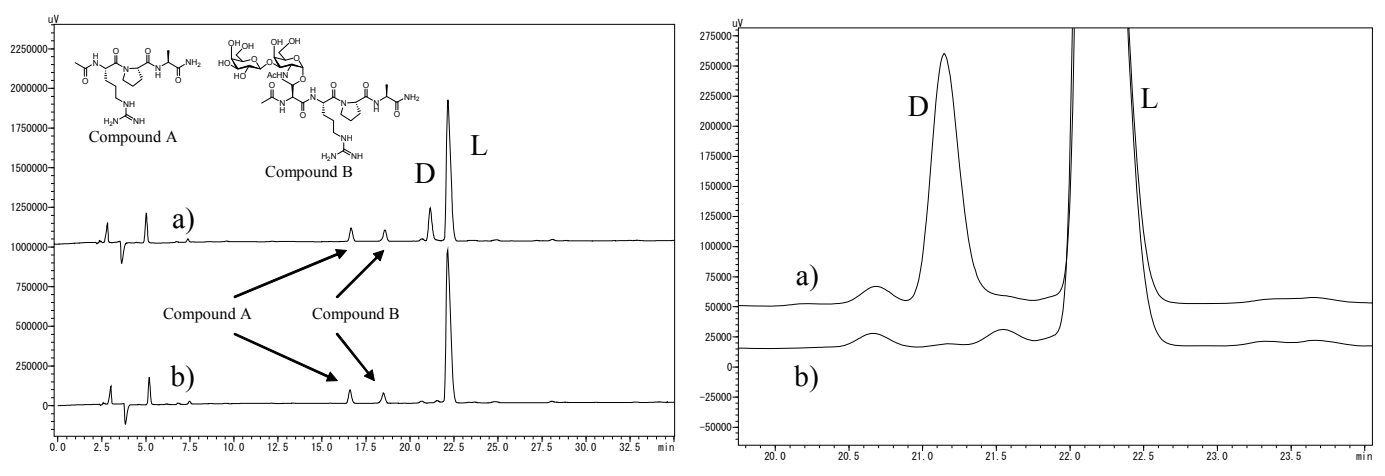

Figure S10. RP-HPLC analysis of the product, Ala-Pro-Asp-Thr(core1)-Arg-Pro-Ala synthesized by the coupling between the peptide segment B (Fmoc-Ala-Pro-Asp $\left(\mathrm{O}^{t} \mathrm{Bu}\right)$ $\mathrm{OH})$ and glycopeptide-bound resin $\left[\mathrm{H}_{2} \mathrm{~N}-\mathrm{Thr}\left((\mathrm{AcO})_{6} \mathrm{core} 1\right)-\mathrm{Arg}(\mathrm{Pbf})-\right.$ Pro-Ala-resin]. a) reaction condition: HTBU, HOBt, DIEA/DMF, b) reaction condition: DIC, $\mathrm{HOOBt} / \mathrm{CH}_{2} \mathrm{Cl}_{2}$. HPLC condition; solvent $\mathrm{A}\left(0.1 \%\right.$ TFA in $\left.\mathrm{H}_{2} \mathrm{O}\right)$ and solvent $\mathrm{B}(0.1 \%$ TFA in $\mathrm{MeCN}$ ), composition of the solvent: 0-30 min in a linear gradient flow from $(A / B)=(98 / 2)$ to $(90 / 10)$, flow rate $1.0 \mathrm{ml} / \mathrm{min}$, detector $\mathrm{UV}$ at $210 \mathrm{~nm}$. 

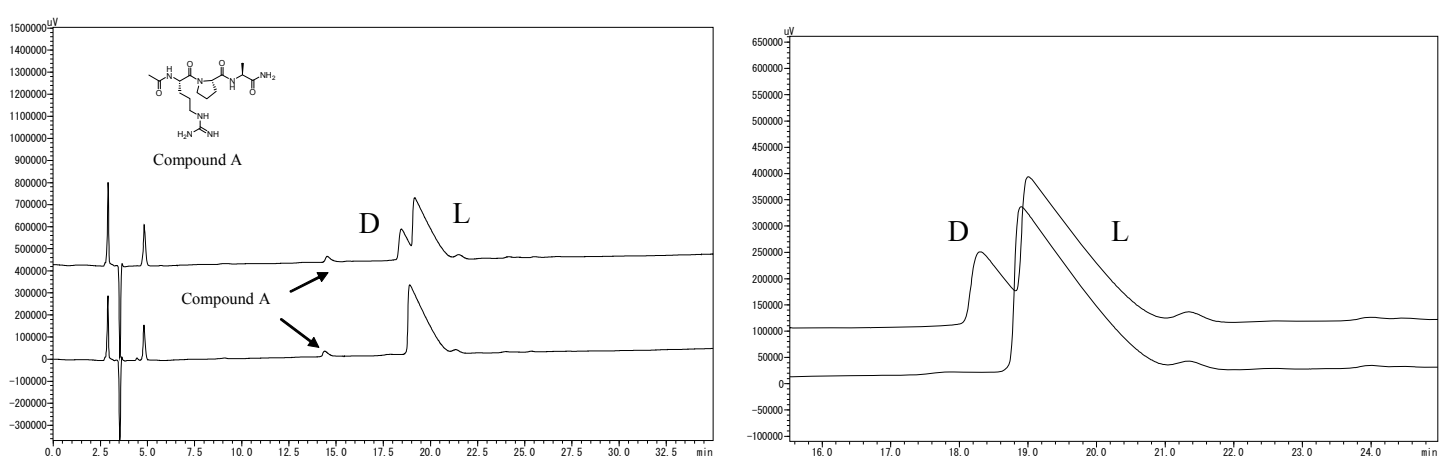

Figure S11. RP-HPLC analysis of the product, Ala-Pro-Asp-Thr(core2)-Arg-Pro-Ala synthesized by the coupling between the peptide segment B (Fmoc-Ala-Pro-Asp $\left(\mathrm{O}^{t} \mathrm{Bu}\right)$ $\mathrm{OH})$ and glycopeptide-bound resin [ $\left.\mathrm{H}_{2} \mathrm{~N}-\mathrm{Thr}\left((\mathrm{AcO})_{7} \mathrm{core} 2\right)-\mathrm{Arg}(\mathrm{Pbf})-\mathrm{Pro}-\mathrm{Ala}-\mathrm{resin}\right]$. a) reaction condition: HTBU, HOBt, DIEA/DMF, b) reaction condition: DIC, $\mathrm{HOOBt} / \mathrm{CH}_{2} \mathrm{Cl}_{2}$. HPLC condition; solvent $\mathrm{A}\left(0.1 \%\right.$ TFA in $\left.\mathrm{H}_{2} \mathrm{O}\right)$ and solvent $\mathrm{B}(0.1 \%$ TFA in MeCN), composition of the solvent: 0-30 $\mathrm{min}$ in a linear gradient flow from $(A / B)=(98 / 2)$ to $(90 / 30)$, flow rate $1.0 \mathrm{ml} / \mathrm{min}$, detector $\mathrm{UV}$ at $210 \mathrm{~nm}$. 

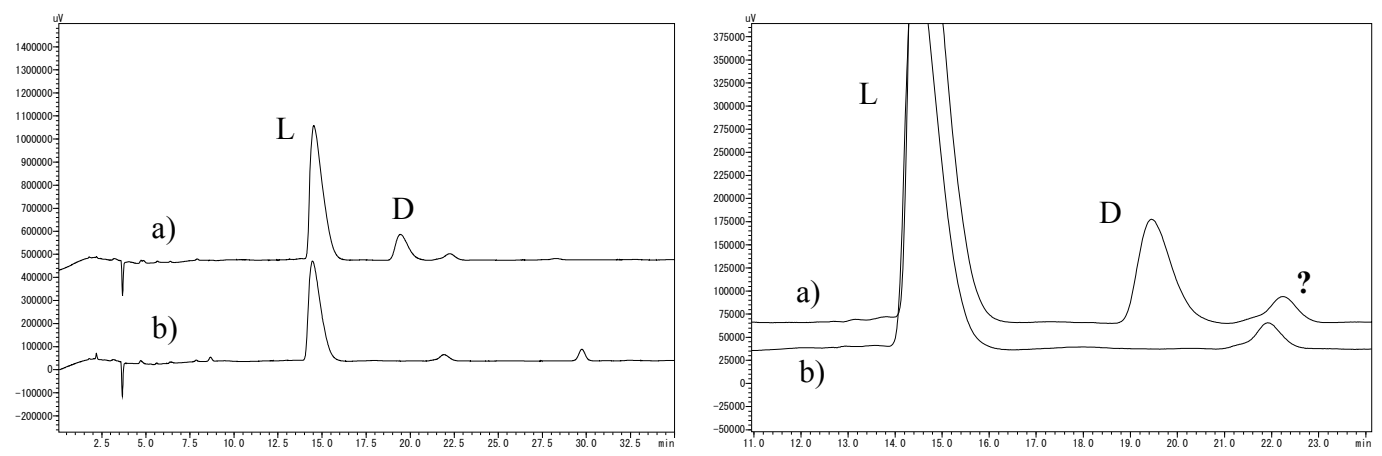

Figure S12. RP-HPLC analysis of the product, Ala-Pro-Pro-Ala-His-Gly-Val-Thr-SerAla synthesized from the coupling between peptide segment C (Fmoc-Ala-Pro-Pro-AlaHis(Trt)-Gly-Val-OH) and peptide-bound resin $\left(\mathrm{H}_{2} \mathrm{~N}-\mathrm{Thr}\left({ }^{\mathrm{t}} \mathrm{Bu}\right)-\mathrm{Ser}\left({ }^{\mathrm{t}} \mathrm{Bu}\right)-\mathrm{Ala}-\mathrm{resin}\right)$. a) reaction condition: HTBU, HOBt, DIEA/DMF, b) reaction condition: DIC, $\mathrm{HOOBt} / \mathrm{CH}_{2} \mathrm{Cl}_{2}$. HPLC condition; solvent $\mathrm{A}\left(0.1 \% \mathrm{FA}\right.$ in $\left.\mathrm{H}_{2} \mathrm{O}\right)$ and solvent $\mathrm{B}(0.1 \%$ FA in $\mathrm{MeCN}$ ), composition of the solvent: $0-30 \mathrm{~min}$ in a linear gradient flow from $(A / B)=(98 / 2)$ to $(95 / 5)$, flow rate $1.0 \mathrm{ml} / \mathrm{min}$, Detector $\mathrm{UV}$ at $210 \mathrm{~nm}$. 

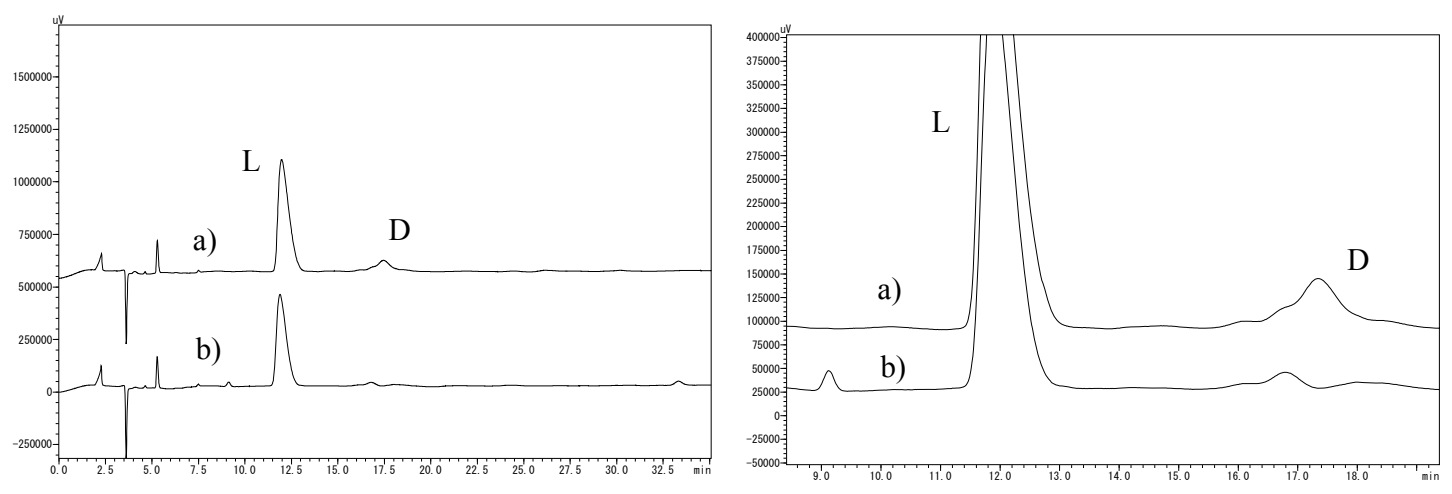

Figure S13. RP-HPLC analysis of the product, Ala-Pro-Pro-Ala-His-Gly-Val-Thr(Tn)Ser-Ala peptides synthesized from the coupling between the peptide segment C (FmocAla-Pro-Pro-Ala-His(Trt)-Gly-Val-OH) and glycopeptide-bound resin $\left[\mathrm{H}_{2} \mathrm{~N}-\right.$ $\left.\operatorname{Thr}\left((\mathrm{AcO})_{3} \mathrm{Tn}\right)-\operatorname{Ser}\left({ }^{\mathrm{t}} \mathrm{Bu}\right)-\mathrm{Ala}-\mathrm{resin}\right]$. a) reaction condition: HTBU, HOBt, DIEA/DMF, b) reaction condition: $\mathrm{DIC}, \mathrm{HOOBt} / \mathrm{CH}_{2} \mathrm{Cl}_{2}$. HPLC condition; solvent $\mathrm{A}(0.1 \% \mathrm{FA}$ in $\left.\mathrm{H}_{2} \mathrm{O}\right)$ and solvent $\mathrm{B}(0.1 \% \mathrm{FA}$ in $\mathrm{MeCN})$, composition of the solvent: $0-30 \mathrm{~min}$ in a linear gradient flow from $(A / B)=(98 / 2)$ to $(95 / 5)$, flow rate $1.0 \mathrm{ml} / \mathrm{min}$, Detector $\mathrm{UV}$ at $210 \mathrm{~nm}$. 


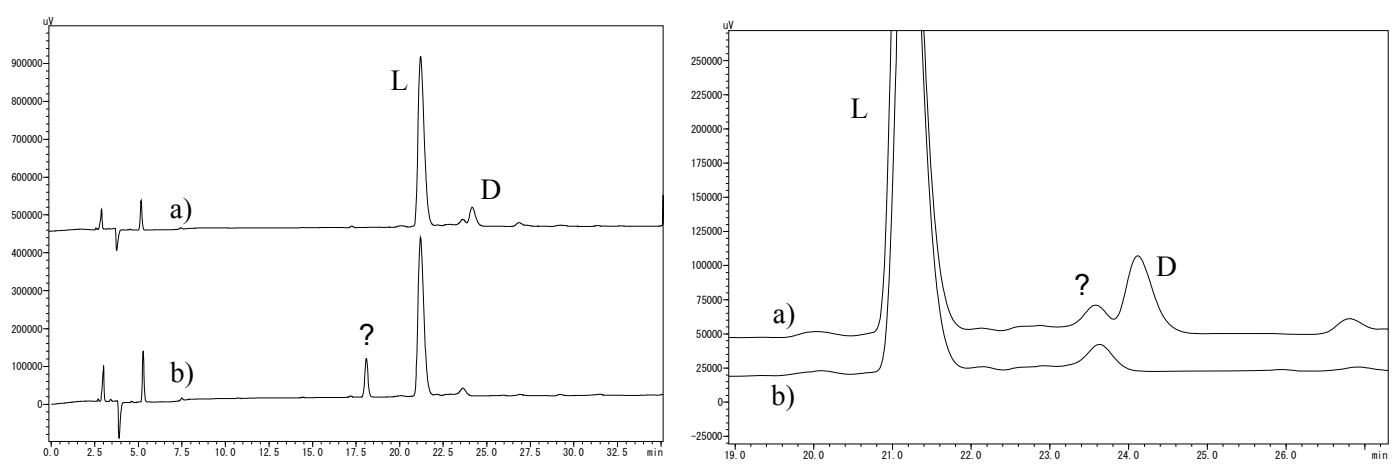

Figure S14. RP-HPLC analysis of the product, Ala-Pro-Pro-Ala-His-Gly-ValThr(core1)-Ser-Ala peptides synthesized from the coupling between the peptide segment C (Fmoc-Ala-Pro-Pro-Ala-His(Trt)-Gly-Val-OH) and glycopeptide-bound resin $\left[\mathrm{H}_{2} \mathrm{~N}-\mathrm{Thr}\left((\mathrm{AcO})_{6} \mathrm{core} 1\right)-\mathrm{Ser}\left({ }^{\mathrm{t}} \mathrm{Bu}\right)\right.$-Ala-resin]. a) reaction condition: HTBU, HOBt, DIEA/DMF, b) reaction condition: DIC, $\mathrm{HOOBt} / \mathrm{CH}_{2} \mathrm{Cl}_{2}$. HPLC condition; solvent A $\left(0.1 \% \mathrm{FA}\right.$ in $\left.\mathrm{H}_{2} \mathrm{O}\right)$ and solvent $\mathrm{B}(0.1 \% \mathrm{FA}$ in $\mathrm{MeCN})$, composition of the solvent: $0-30$ min in a linear gradient flow from $(\mathrm{A} / \mathrm{B})=(98 / 2)$ to $(95 / 5)$, flow rate $1.0 \mathrm{ml} / \mathrm{min}$, Detector UV at $210 \mathrm{~nm}$. 

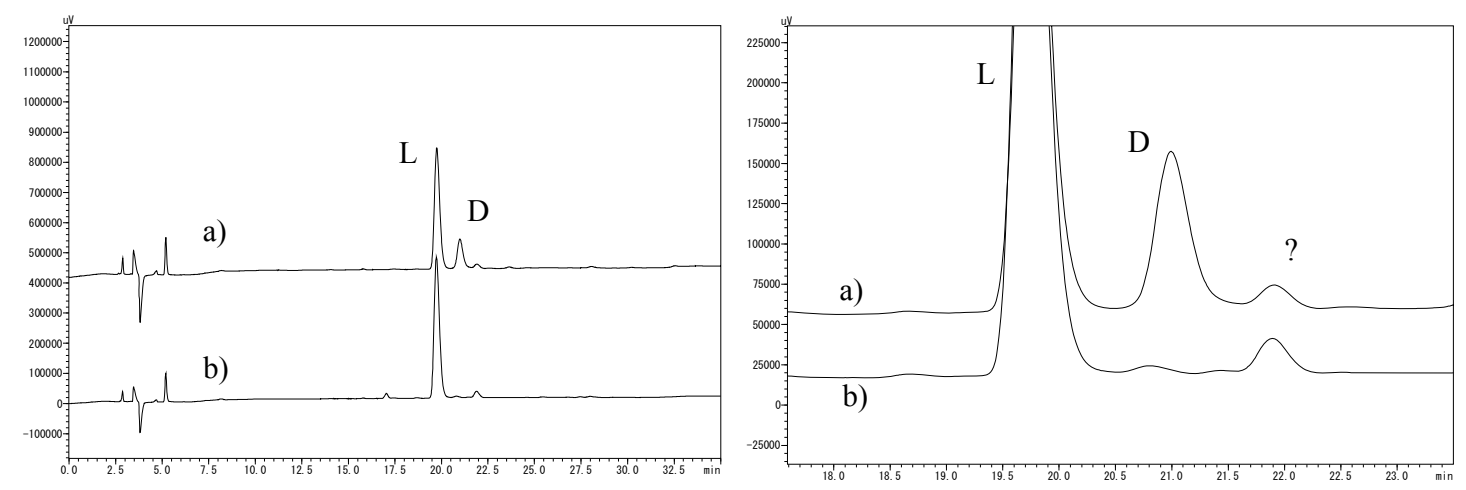

Figure S15. RP-HPLC analysis of the product, Ala-Pro-Pro-Ala-His-Gly-ValThr(core2)-Ser-Ala peptides synthesized from the coupling between the peptide segment C (Fmoc-Ala-Pro-Pro-Ala-His(Trt)-Gly-Val-OH) and glycopeptide-bound resin $\left[\mathrm{H}_{2} \mathrm{~N}-\mathrm{Thr}\left((\mathrm{AcO})_{7} \mathrm{core} 2\right)-\mathrm{Ser}\left({ }^{\mathrm{t}} \mathrm{Bu}\right)\right.$-Ala-resin]. a) reaction condition: HTBU, HOBt, DIEA/DMF, b) reaction condition: DIC, $\mathrm{HOOBt} / \mathrm{CH}_{2} \mathrm{Cl}_{2}$. HPLC condition; solvent A $\left(0.1 \%\right.$ FA in $\left.\mathrm{H}_{2} \mathrm{O}\right)$ and solvent $\mathrm{B}(0.1 \% \mathrm{FA}$ in $\mathrm{MeCN})$, composition of the solvent: $0-30$ min in a linear gradient flow from $(\mathrm{A} / \mathrm{B})=(98 / 2)$ to $(95 / 5)$, flow rate $1.0 \mathrm{ml} / \mathrm{min}$, Detector UV at $210 \mathrm{~nm}$. 


\section{Convergent solid-phase synthesis of 77-mer MUC1 glycopeptides.}

Synthesis of 77-mer asialo-MUC1 glycopeptide (6). The synthesis of the 77-mer MUC1 glycopeptides was performed by condensing a 3-fold molar excess of protected peptide segments A-C and 2-fold molar excess of Fmoc protected sugar amino acids such as $\quad N^{\alpha}$-Fmoc-Thr((AcO) $)_{3}$ GalNAc $\left.\alpha\right)-O H, \quad N^{\alpha}$-Fmoc$\operatorname{Thr}\left((\mathrm{AcO})_{4} \mathrm{Gal} \beta 1 \rightarrow 3(\mathrm{AcO})_{2}\right.$ GalNAc $\left.\alpha\right)-\mathrm{OH}, \quad \quad N^{\alpha}$-Fmoc$\operatorname{Thr}\left((\mathrm{AcO})_{4} \mathrm{Gal} \beta 1 \rightarrow 3\left[(\mathrm{AcO})_{3} \mathrm{GlcNAc} \beta 1 \rightarrow 6\right] \mathrm{GalNAc} \alpha\right)-\mathrm{OH}, \quad N^{\alpha}$-Fmoc$\operatorname{Ser}\left((\mathrm{AcO})_{3} \mathrm{GalNAc \alpha}\right)-\mathrm{OH}, \quad$ and $\quad N^{\alpha}$-Fmoc$\operatorname{Ser}\left((\mathrm{AcO})_{4} \mathrm{Gal} \beta 1 \rightarrow 3\left[(\mathrm{AcO})_{3} \mathrm{GlcNAc} \beta 1 \rightarrow 6\right] \mathrm{GalNAc} \alpha\right)-\mathrm{OH} \quad$ over the resin-bound amino component. The protected segments A-C were applied as a solution in $\mathrm{CH}_{2} \mathrm{Cl}_{2}$ with condensing agents DIC and HOOBt under the microwave irradiation. After 1-2 hr of condensation, unreacted remaining $N$-terminal amino groups were capped by acetylation using an excess acetic anhydride and DIEA in DMF. The Fmoc protected sugar amino acids were applied as a solution in DMF with condensing agents HBTU, HOOBt and DIEA and the mixture was kept for 20 min under the microwave irradiation. ${ }^{\text {S16-18 }}$ Then $N$-terminal Fmoc group was removed by treatment with $20 \%$ piperidine in DMF. After conducting each condensation reactions, the resin-bound glycopeptide intermediates were cleaved, deprotected and analyzed by MALDI-TOFMS and Kaiser Test to assess the reaction processes. After the final coupling step, the resin-bound glycopeptides were treated with $20 \%$ piperidine, washed with $\mathrm{CH}_{2} \mathrm{Cl}_{2}$ and dried. The residual resin was treated with cleavage cocktail (TFA: $\mathrm{H}_{2} \mathrm{O}: \mathrm{TIS}=95: 2.5: 2.5$ ) for $2 \mathrm{hr}$ at room temperature. The crude product was precipitated in ice-cold ether, washed with ether, and then lyophilized. The crude MUC1 glycopeptide was purified by RP-HPLC [column, Inertsil ODS-3 $(10 \times 250 \mathrm{~mm})$; flow rate, $4.0 \mathrm{ml} / \mathrm{min}$; elution buffer A: $\mathrm{H}_{2} \mathrm{O}$ containing $0.1 \%$ FA, elution buffer $\mathrm{B}$ : $\mathrm{CH}_{3} \mathrm{CN}$ containing $0.1 \%$ FA, composition; $0-45 \mathrm{~min}$ in linear gradient flow from $(\mathrm{A} / \mathrm{B})=(98 / 2)$ to $(50 / 50), \mathrm{UV}$ detector monitoring at $220 \mathrm{~nm}$ ], and the fractions containing target material was 
collected and lyophilized to afford $O$-acetylated 77-mer MUC1 glycopeptide as an amorphous solid $(29.9 \mathrm{mg})$. To remove all acetyl protections of the hydroxyl groups as well as methyl protections of carboxyl groups at sialic acid residues, the material was dissolved in a solution of $1 \mathrm{M} \mathrm{NH}_{3}$ in $\mathrm{MeOH}$, and the mixture was stand at $4{ }^{\circ} \mathrm{C}$ for 16 hrs. The solvent was removed by evaporation in vacuo. Then, the residue was dissolved in the solution of $\mathrm{NaOHaq} \cdot \mathrm{-MeOH}(\mathrm{pH} 11.5)$ and the mixture was stirred at room temperature for $30 \mathrm{~min}$. The reaction mixture was neutralized with $10 \% \mathrm{AcOH}$ aq. and evaporated in vacuo. The residual crude product was purified by RP-HPLC [column, Inertsil ODS-3 $(10 \times 250 \mathrm{~mm})$; flow rate, $4.0 \mathrm{ml} / \mathrm{min}$; elution buffer $\mathrm{A}, \mathrm{H}_{2} \mathrm{O}$ containing $0.1 \% \mathrm{FA}$; elution buffer $\mathrm{B}, \mathrm{CH}_{3} \mathrm{CN}$ containing $0.1 \% \mathrm{FA}$, composition; 0-45 min in linear gradient flow from $(A / B)=(98 / 2)$ to $(50 / 50)$, UV detector monitoring at $220 \mathrm{~nm}$ ] and the fraction containing product was collected and lyophilized to afford target MUC glycopeptide 6 as an amorphous solid in 4.2\% overall yield $(9.7 \mathrm{mg}, 0.88 \mu \mathrm{mol}$ ) from the first solid-supported coupling reaction: MALDI-TOFMS: $\mathrm{m} / \mathrm{z}$ calcd for $\mathrm{C}_{455} \mathrm{H}_{726} \mathrm{~N}_{110} \mathrm{O}_{205} \quad[\mathrm{M}+\mathrm{H}]^{+}$11012.0, found 11017.9. ESI-MS: $\mathrm{m} / \mathrm{z}$ calcd for $\mathrm{C}_{455} \mathrm{H}_{727} \mathrm{~N}_{110} \mathrm{O}_{205}[\mathrm{M}+\mathrm{H}]$ 11018.0010, found 11017.9954. Amino acid analysis: Ala(16) 15.9, Asp(4) 4.0, Arg(4) 4.0, Gly(7) 6.8, His(3) 2.7, $\operatorname{Pro}(20)$ 21.1, $\operatorname{Ser}(8)$ 6.9, $\operatorname{Thr}(12)$ 11.8, $\operatorname{Val}(3) 2.9$ (see, also Figure S16).

\section{IV-2. Enzymatic conversion from compound 6 into 77-mer sialyl-MUC1 (1).} Asialo-MUC1 glycopeptide $6(2.2 \mathrm{mg}, 0.2 \mu \mathrm{mol})$ was modified by using $70 \mathrm{mU}$ of $\alpha 2,3-(O)-S i a T$ and CMP-Neu5Ac $(1.95 \mathrm{mg}, 3.0 \mu \mathrm{mol})$ in a total volume of $1.5 \mathrm{ml}$ of 50 $\mathrm{mM}$ HEPES buffer ( $\mathrm{pH} 7.0$ ) containing $10 \mathrm{mM} \mathrm{MnCl}_{2}$ and $0.1 \%$ BSA. ${ }^{\mathrm{S} 19, \mathrm{~S} 20}$ The progress of the enzymatic sialylation of precursor $\mathbf{6}$ to compound $\mathbf{1}$ was monitored by HPLC and MALDI-TOFMS (Figure S16). After incubation for $20 \mathrm{hr}$ at $25^{\circ} \mathrm{C}$, the reaction mixture was subjected to the purification by RP-HPLC [column, Inertsil ODS$3(10 \times 250 \mathrm{~mm})$; flow rate, $4.0 \mathrm{ml} / \mathrm{min}$; elution buffer $\mathrm{A}, \mathrm{H}_{2} \mathrm{O}$ containing $0.3 \% \mathrm{FA}$; elution buffer $\mathrm{B}, \mathrm{CH}_{3} \mathrm{CN}$ containing $0.3 \% \mathrm{FA}$, composition: $0-45 \mathrm{~min}$ in linear gradient 
flow from $(\mathrm{A} / \mathrm{B})=(98 / 2)$ to $(80 / 20)$, UV detector monitoring at $220 \mathrm{~nm}$ ] to give fully sialylated MUC1 model 1 (2.0 mg, $83 \%)$ : MALDI-TOFMS: $\mathrm{m} / \mathrm{z}$ calcd for $\mathrm{C}_{521} \mathrm{H}_{828} \mathrm{~N}_{116} \mathrm{O}_{253} \quad[\mathrm{M}+\mathrm{H}]^{+}$12758.6, found 12774.5. ESI-HRMS: $\mathrm{m} / \mathrm{z}$ calcd for $\mathrm{C}_{521} \mathrm{H}_{829} \mathrm{~N}_{116} \mathrm{O}_{253}[\mathrm{M}+\mathrm{H}]$ 12765.5765, found 12765.5772 (see, also Figure S16). 


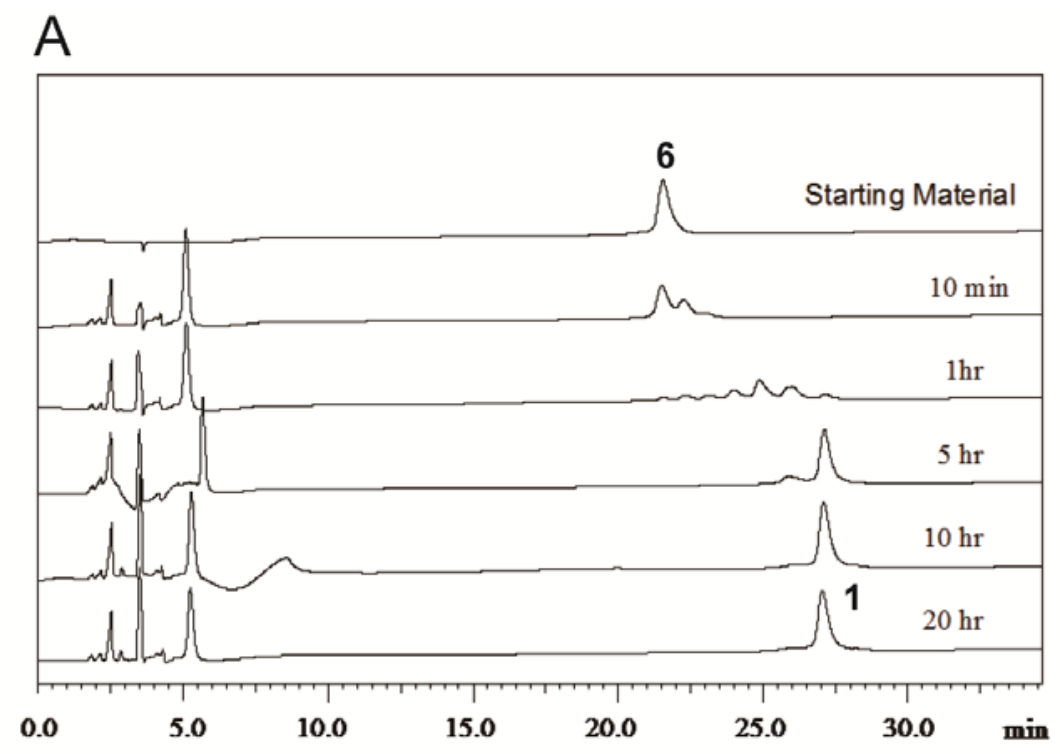

B

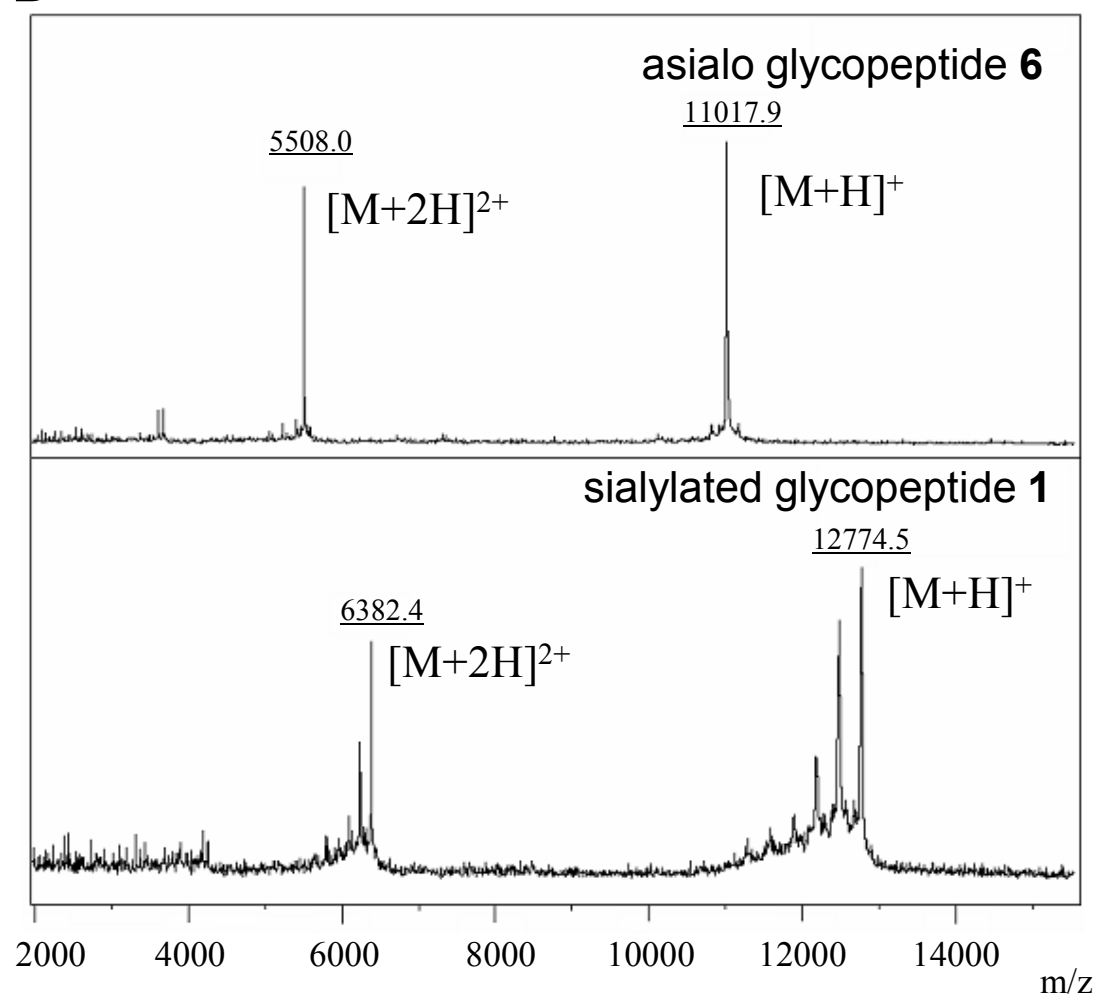




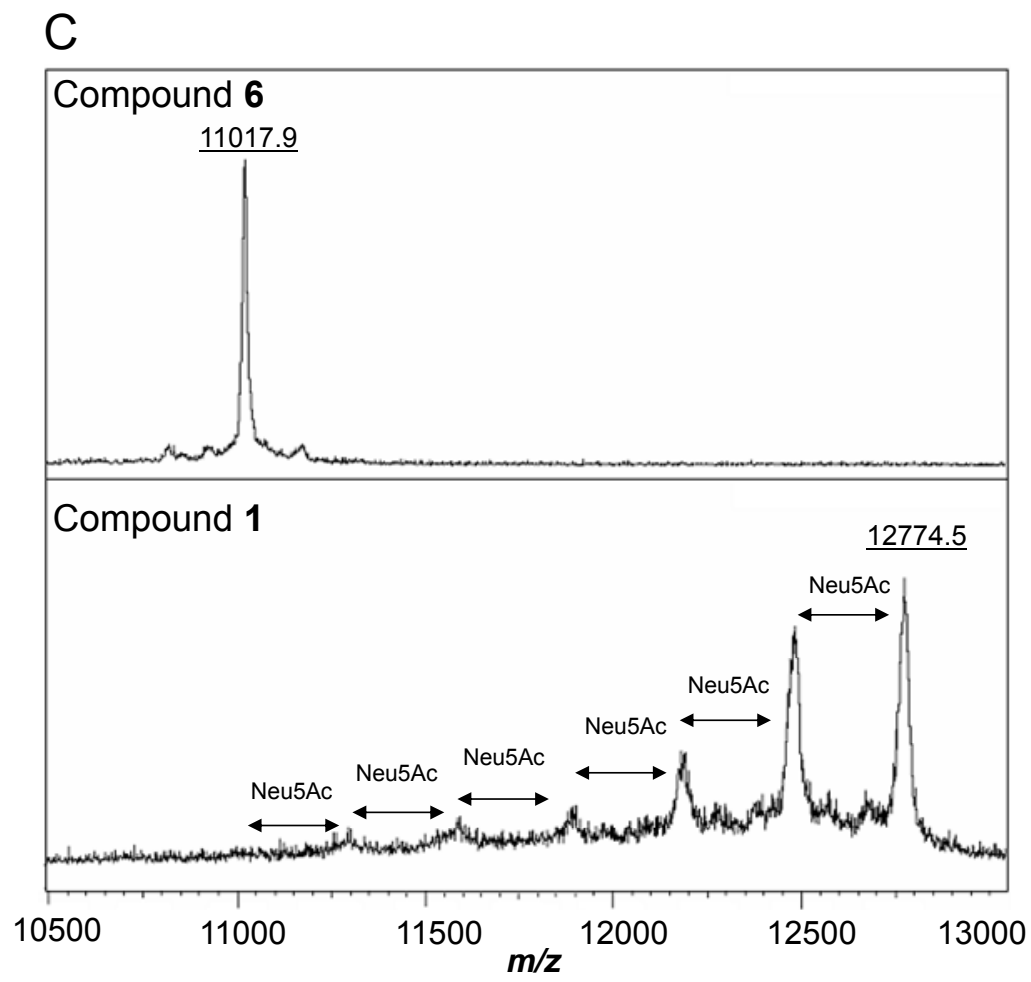

Figure S16. Synthesis of MUC1 models 6 and 1. (A) HPLC profiles of the enzymatic sialylation from precursor 6 into compound 1. The results showed that enzymatic glycosylation at the potential 6 sialylation sites were mostly completed for $1 \mathrm{hr}$. (B) MALDI-TOFMS of compound $\mathbf{6}$ and 1, showing molecular mass ions, respectively. (C) As anticipated, it seemed likely that laser-irradiation induced partial deletion of the sialic acids at 6 potential sialylation sites in the compound $\mathbf{1}$ under the negative ion mode while ESI-HRMS (see, Figure 3 in the main text) showed quantitative introduction of sialic acid residues at all potential acceptor substrates. 
Chiral purity of 77-mer MUC1 glycopeptides tested by Marfey's method. 77-mer MUC1 model $1(0.5 \mathrm{mg})$ was hydrolyzed at $110^{\circ} \mathrm{C}$ for $3-10 \mathrm{hr}$ with $6 \mathrm{~N} \mathrm{HCl}$. The solution was evaporated in vacuo and the residue was dissolved in $\mathrm{H}_{2} \mathrm{O}(50 \mu 1)$. To this solution was added $20 \mu \mathrm{l}$ of $1 \mathrm{M} \mathrm{NaHCO}_{3}$ and $100 \mu \mathrm{l}$ of $1 \%$ L-FDLA (1-fluoro-2,4dinitrophenyl-5-L-leuicinamide) in acetone. ${ }^{\mathrm{S} 21, \mathrm{~S} 22}$ After incubation at $37^{\circ} \mathrm{C}$ for $1 \mathrm{hr}$, the reaction mixture was quenched by the addition of $20 \mu \mathrm{l}$ of $1 \mathrm{~N} \mathrm{HCl}$ and diluted with $50 \% \mathrm{CH}_{3} \mathrm{CN}$ aq.. The solution was subjected to the analysis by photodiode array detector (PAD) and ESI-LC/MS. Diastereomeric amino acid derivatives were characterized by using RP-HPLC under the condition below [column, Inertsil ODS-3 (4.6 x $250 \mathrm{~mm}$ ); flow rate, $1.0 \mathrm{ml} / \mathrm{min}$; elution buffer $\mathrm{A}: \mathrm{H}_{2} \mathrm{O}$ containing $0.1 \% \mathrm{FA}$, elution buffer $\mathrm{B}$ : $\mathrm{CH}_{3} \mathrm{CN}$ containing $0.1 \% \mathrm{FA}$, composition: 0-45 min in linear gradient flow from $(\mathrm{A} / \mathrm{B})=(80 / 20)$ to $(30 / 70)$, UV detector monitoring at $340 \mathrm{~nm}$ and mass detector monitoring selective ion mode] (Figure S17).

\section{Characterization of synthetic MUC1 glycopeptides by ELISA (EITEST ${ }^{\circledR}$ KL6).} Immunological characterization of the synthetic MUC1 glycopeptides $\mathbf{1}$ and $\mathbf{6}$ was performed by using EITEST $^{\circledR}$ KL6 kit (Sanko Junyaku Co., Ltd. Tokyo, Japan) according to the protocol recommended in this diagnostic assay system. The microtiter plate coated with anti-KL6 mAb was added synthetic 77-mer MUC1 glycopeptides or KL6/MUC1 calibrator glycoprotein sample diluted with a reaction buffer. The reaction mixture was kept at room temperature for $2 \mathrm{hr}$. Then each well was washed 3 times with the washing buffer. Anti-KL6 mAb conjugated with HRP in the reaction buffer was added $(100 \mu \mathrm{l} /$ well). After incubation at room temperature for $1 \mathrm{hr}$, the wells were washed 3 times with the washing buffer. The substrate solution was added (100 $\mu 1 /$ well) and the mixture was stand for $30 \mathrm{~min}$. Then, the reaction was terminated with the addition of $100 \mu \mathrm{l} /$ well of stop solution. The rates of the reaction in each well were determined by measuring the absorbance at $405 \mathrm{~nm}$. 

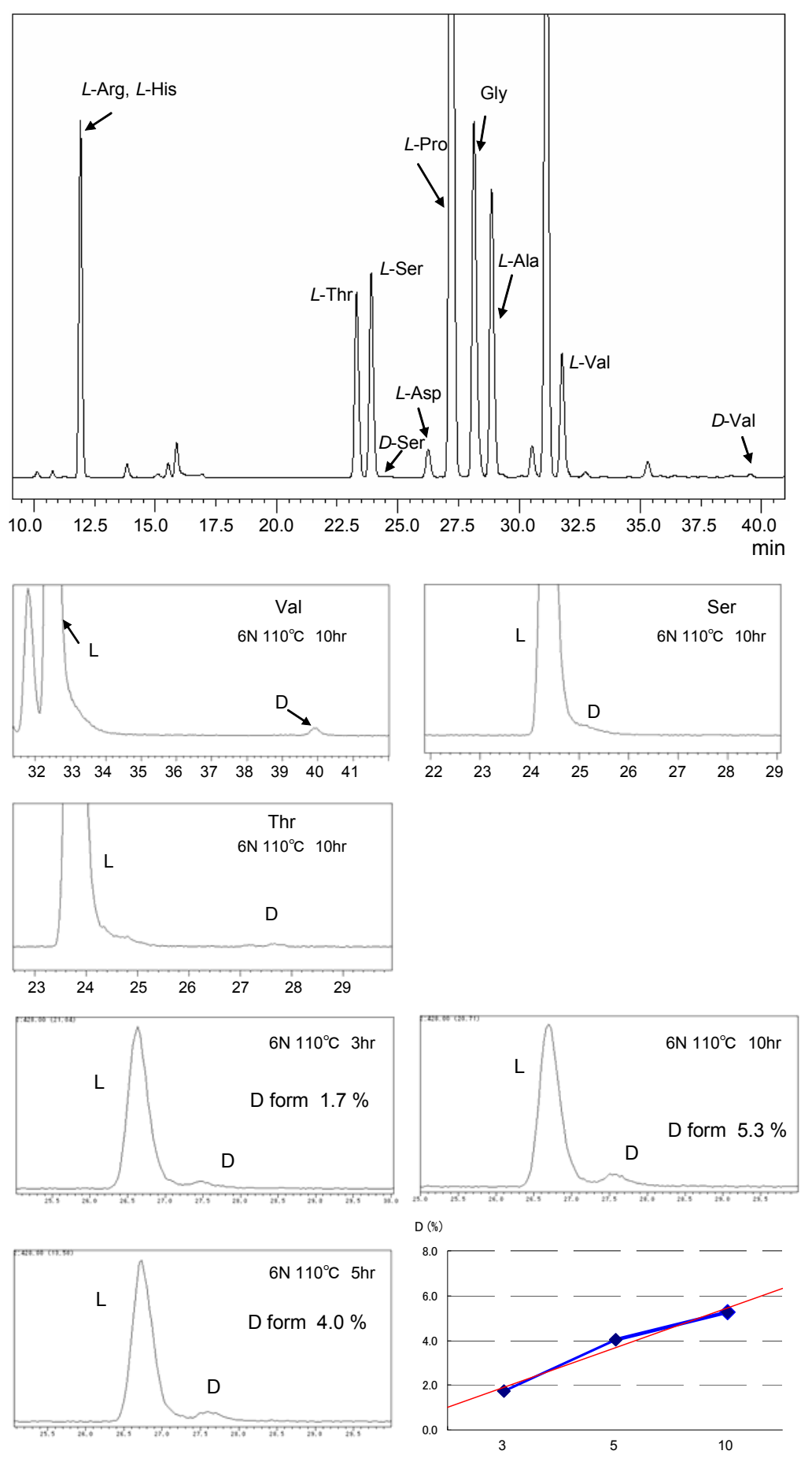

Figure S17. RP-HPLC profile of the crude L-FDLA amino acid derivatives obtained by the treatment with Marfey's reagent (L-FDLA) after $10 \mathrm{hr}$. The chromatogram was monitored with UV detector at $340 \mathrm{~nm}$. Each chromatogram with SIM (selected ion monitoring) mode LC-MS showed L-FDLA derivatives of Val, Ser and Thr, respectively. In case for the LC-MS of the L-FDLA-Asp derivative, it was revealed that the treatment with $\mathrm{HCl}$ at $110^{\circ} \mathrm{C}$ can cause epimerization dependent on the reaction time $(3,5$, and $10 \mathrm{hrs})$. 


\section{References}

S1. L. Zhang, W. Rapp, C. Goldhammer, E. Bayer E. In Innovations and Perspectives in Solid Phase Synthesis. Peptides, Proteins and Nucleic Acids. Biological and Biomedical Applications, R. Epton Ed., Mayflower Worldwide Ltd., Birmingham 1994, pp.717-718.

S2. C. Zikos, N. G. Ferderigos, Tetrahedron Lett. 1994, 35, 1767-1770.

S3. H. Rink, Tetrahedron Lett. 1987, 28, 3787-3790.

S4. M. S. Bernatowicz, S. B. Daniels. H. Köster. Tetrahedron Lett. 1989, 30, 4645-4648.

S5. R. Knorr, A. Trzeciak, W. Bannwarth, D. Gillessen, Tetrahedron Lett. 1989, 30, 1927-1930.

S6. W. Koenig, A. Volk, Chem. Ber. 1977, 110, 1-11.

S7. N. Mathieux, H. Paulsen, M. Meldal, K. Bock, J. Chem. Soc., Prekin Trans.1 1997, $2359-2368$.

S8 E. Meinjohanns, M. Meldal, A. Schleyer, H. Paulsen, K. Bock, J. Chem. Soc., Perkin Trans.1 1996, 985-993.

S9. H. Tanaka, M. Adachi, T. Takahashi, Chem. Eur. J. 2005, 11, 849-862.

S10. D. Qiu, S. S. Gandhi, R. R. Koganty, Tetrahedron Lett. 1996, 37, 595-598.

S11. König, W. Geiger, R. Chem Ber. 1970, 103, 2024-2033.

S12. König, W. and Geiger, R. Chem Ber 1970, 103, 2034-2040.

S13. Carpino, L. A. J. Am. Chem. Soc. 1993, 115 4397-4398. 
S14. Carpino, L. A. and El-Faham, A. J. Org. Chem. 1995, 60, 3561-3564.

S15. Sabatino, G., Mulinacci, B., Alcaro, M.C., Chelli, M., Rovero, P. and Papini, A. M. Lett. Peptide Sci. 2003, 9, 119-123.

S16. Matsushita, T., Hinou, H., Kurogochi, M., Shimizu, H. and Nishimura, S.-I. Org. Lett. 2005, 7, 877-880.

S17. Matsushita, T., Hinou, H., Fumoto M., Kurogochi, M., Fujitani, N., Shimizu, H., Nishimura, S-I. J. Org. Chem. 2006, 71, 3051-3063.

S18. Naruchi, K. Hamamoto, T., Kurogochi, M., Hinou, H., Shimizu H., Matsushita, T., Fujitani, N., Kondo, H. and Nishimura, S-I. J. Org. Chem. 2006, 71, 9609-9621.

S19. Fumoto, M., Hinou, H., Matsushita, T., Kurogochi, M., Ohta, T., Ito, T., Yamada, K., Takimoto, A., Kondo, H., Inazu, T. and Nishimura, S.-I. Angew. Chem. Int. Ed. 2005, 44, 2534-2537.

S20. Fumoto, M., Hinou, H., Ohta, T., Ito, T., Yamada, K., Takimoto, A., Kondo, H., Shimizu, H., Inazu, T., Nakahara, Y., Nishimura, S.-I. J. Am. Chem. Soc. 2005, 127, 11804-11818.

S21. Fujii, K., Ikai, Y., Oka, H., Suzuki, M., and Harada, K-I. Anal. Chem. 1997, 69, $5146-5151$.

S22. B'Hymer, C., Montes-Bayon, M. and Caruso, J. A. J. Sep. Sci. 2003, 26, 7-19. 